\title{
Law and Ethics: Ethics Associated with Energy Resources Development Operations Exemplified by Petroleum Development Operations in Nigeria
}

\author{
Edward T. Bristol-Alagbariya \\ Associate Dean \& Senior Multidisciplinary Lecturer, Faculty of Law, University of Port Harcourt, \\ NIGERIA; Affiliate Visiting Fellow, University of Aberdeen, UNITED KINGDOM; and Visiting Research \\ Fellow, Centre for Energy, Petroleum \& Mineral Law and Policy (CEPMLP), Graduate School of Natural \\ Resources Law, Policy \& Management, University of Dundee, Scotland, UNITED KINGDOM \\ * E-mail of the corresponding author: ebristolalagbariya@gmail.com
}

\begin{abstract}
Energy resources may be described as different categories of fuels used by the humans for heating, generation of electrical energy and other forms of energy conversion processes. These resources are therefore the sources from which energy is derived, produced and supplied for the use of human beings and overall benefit of society. Energy resources are necessary for the day-to-day sustenance and survival of humans and society at large. Energy resources promote the functionality, viability and vitality of other sectors of a country's economy. The ability of humans to harness energy resources is arguably the most important step in the history of human civilisation. The sources of global energy supply (energy resources) may be considered in two broad categories, namely non-renewable and renewable resources. Petroleum, a focal point of this study, is an example of fossil fuels. Petroleum resources are energy and major natural resources. These resources development operations are extractive industrial operations, which have tremendous negative effects on the environment and inhibit sustainable development. The adverse consequences of petroleum energy and major natural resources development operations affect the oil-rich ethnic minority Delta region and other oil producing areas of Nigeria, as well as the entire Nigerian nation. In the perspective of this study, ethics may be considered as a wide and exploratory subject of discourse, which appears like an elephant that may be described from many standpoints. Obviously, there are certain ethics, ethical issues or ethical conducts (morally good practices) associated with energy and major natural resources development operations in particular and the entire life-cycle of these resources activities in general, which are designed to promote effective energy resource operations, towards affordable, reliable, sustainable and efficient modern energy services to all societies and individuals around the globe. Law is a system of binding modes of conduct, which are formulated to govern behavioural patterns, namely the behaviour of individuals, groups and entities in society. The aim of this socio-legal study is to examine the role of law as a mechanism of social engineering, positive change and dynamic progress in society, towards providing access to energy services for all (overall public good), by 2030 (the target year proclaimed by the $U N$ ) regarding delivery of sustainable modern energy services to all. The study arrives at the finding that law remains a significant and inevitable tool for governing behavioural patterns; nevertheless, in developing countries suffering from energy poverty like Nigeria, law is unfortunately an unresolved necessity in respect of governing energy resources operations for the daily sustenance and survival of humans and society at large.
\end{abstract}

Keywords: Law; Ethics; Energy Resources; Extractive Industrial Operations (EIOs); Petroleum Resources; Non-renewable Resources; Renewable Energy Resources; Sustainable Development (SD); Nigeria; Niger Delta; Bad Political Leadership (Bad Governance); Good Governance; Morality (Morality-in-action: Morally Good Actions); Natural Law (Natural Law School of Thought); Positive Law Theory (Positive Law School of Thought).

DOI: $10.7176 / \mathrm{IAGS} / 81-09$

Publication date:April $30^{\text {th }} 2020$

\section{Introduction}

Energy resources may be considered as all manner of fuels used by the humans for heating, generation of electrical energy and other forms of energy conversion processes. These resources are the sources from which energy is derived, produced and supplied for the use of human beings and overall benefit of society. ${ }^{1}$ The

\footnotetext{
${ }^{1}$ R. L. Bradley (Jnr) and R. W. Fulmer, Energy The Master Resource (Kendall/Hunt Publishing Co. 2004$), 4$.
} 
significance of energy resources to humans and society at large cannot be overemphasised, as these resources help to nourish and sustain life. Energy resources are necessary for the daily sustenance and survival of humans and society at large. ${ }^{1}$ They are crucial and inevitable to the development, advancement and overall prosperity of the human race and society as a whole. ${ }^{2}$ Energy resources enhance the functionality, viability and vitality of other sectors to the economy of a country. ${ }^{3}$ The ability of humans to harness energy resources is arguably the most important step in the history of human civilisation. ${ }^{4}$

The sources of global energy supply (energy resources) may be considered in two broad categories, namely non-renewable and renewable resources. ${ }^{5}$ Petroleum, a focal point of this study, is an example of fossil fuels, which constitute most of the world's non-renewable energy resources. ${ }^{6}$

From the period of the industrial revolution in Great Britain in the $18^{\text {th }}$ Century, to the $2^{\text {nd }}$ half of the $20^{\text {th }}$ Century, fossil fuels were the dominant forms of the world's energy resources. Great Britain led the world into industrialisation in the $18^{\text {th }}$ Century, when machines were powered by coal, consequent upon which electricity produced from burning coal, began to take over from manual labour. ${ }^{7}$ Based on the trend of consumption of energy resources and their related services, some consider that petroleum resources, which are non-renewable fossil fuels' variety of energy resources, ${ }^{8}$ would continue to be the major sources of the world's energy supply in the ongoing $21^{\text {st }}$ Century. ${ }^{9}$

Petroleum resources are energy and major natural resources. These resources development operations are extractive industrial operations (EIOs), which have colossal negative effects on the environment and inhibit sustainable development (SD). ${ }^{10}$ The enormous adverse consequences of petroleum energy and major resources development operations affect the oil-rich ethnic minority Delta region and other oil producing areas of Nigeria, ${ }^{11}$ as well as the entire Nigerian nation.

${ }^{1}$ World Commission on Environment and Development (WCED), Our Common Future (Oxford University Press 1987), 168, 171 and 181-189.

2 Ibid; D. D. Dears, Energy: The Source of Prosperity by Donn Dears (Donn D. Dears LLC 2019); H. H. Schobert, Energy and Society: An Introduction (CRC Press 2014), 1-10; T. Jackson, Prosperity without Growth?: The Transition to a Sustainable Economy (Sustainable Development Commission 2009); T. Jackson, Prosperity without Growth: Economics for a Finite Planet (Earthscan 2011).

${ }^{3}$ A. Adenikinju et al (eds), Energy Resource Management in a Federal System: Challenges, Constraints and Strategies: Proceedings of the 2013 NAEE/IAEE Conference (Nigerian Association of Energy Economics 2014), $27-28$.

${ }^{4}$ World Energy Council (WECouncil), World Energy Resources 2016 (WECouncil 2016).

${ }^{5}$ A. Adenikinju et al (eds) (n4), 223 and 417-500; College of Agricultural Sciences, The Pennsylvania State University, 'Renewable and Nonrenewable Resources' < $\underline{\text { https://extension.psu.edu/renewable-and-nonrenewable- }}$ resources $>$ Accessed 27 April, 2020.

${ }^{6}$ O. C. Kopp (Encyclopædia Britannica), 'Fossil Fuel <https://www.britannica.com/science/fossil-fuel $>$; Environmental and Energy Study Institute (EESI), 'Fossil Fuels' <https://www.eesi.org/topics/fossilfuels/description> both Accessed 27 April, 2020.

${ }^{7} \mathrm{Ibid}$; D. D. Dears (n3), particularly 5-7.

8 National Geographic Society, 'Petroleum' <https://www.nationalgeographic.org/encyclopedia/petroleum/> Accessed 27 April, 2020.

${ }^{9}$ Organization of the Petroleum Exporting Countries (OPEC), 'Petroleum will still be the major energy resource in the $21^{\text {st }}$ Century' $<$ https://www.opec.org/opec web/en/press room/902.htm $>$ Accessed 27 April, 2020.

${ }^{10}$ International Institute for Environment and Development (IIED) and World Business Council for Sustainable Development (WBCSD), Breaking New Ground: Mining, Minerals and Sustainable Development: The Report of the MMSD Project (Earthscan 2002); World Bank Group, 'Striking a Better Balance - The World Bank Group and Extractive Industries: The Final Report of the Extractive Industries Review, World Bank Group Management Response' $\quad<$ http://documents.worldbank.org/curated/en/961241468781797388/pdf/300010GLB.pdf $>$; The World Bank, 'Extractive Industries' <https://www.worldbank.org/en/topic/extractiveindustries > both Accessed 27 April, 2020; E. T. Bristol-Alagbariya, Participation in Petroleum Development: Towards Sustainable Community Development in the Niger Delta (Centre for Energy, Petroleum \& Mineral Law \& Policy [CEPMLP]/Dundee University Press [DUP] 2010), 83-101, especially 100.

${ }^{11}$ B. Manby, The Price of Oil: Corporate Responsibility and Human Rights Violations in Nigeria's Oil Producing Communities (Human Rights Watch 1999); I. Gary and T. L. Karl., Bottom of the Barrel: Africa's Oil Boom and the Poor (Catholic Relief Services 2003); O. Douglas and I. Okonta, Where Vultures Feast: Shell, Human Rights, and Oil in the Niger Delta (Sierra Club 2001); A. A. Ikein, The Impact of Oil on a Developing Country: The Case of Nigeria (Praeger Publishers 1990); J. G. Frynas, Oil in Nigeria: Conflict and Litigation between Oil Companies and Village Communities (Lit Verlag 2000); J. G. Frynas, Oil in Nigeria: Community Rights and Corporate Dominance in Conflict (Lit Verlag 2000); D. A. Omoweh, Shell Petroleum Development 
In the context of this study, ethics may be considered as a wide and exploratory subject-matter, which appears like an elephant that may be described from many standpoints. Clearly, there are certain ethics, ethical issues or ethical conducts (morally good practices) ${ }^{1}$ associated with energy and major natural resources development operations in particular and the entire life-cycle of these resources activities in general, which are designed to promote effective energy resource operations, towards affordable, reliable, sustainable and efficient modern energy services to all societies and individuals around the globe. ${ }^{2}$

Law is a system of binding modes of conduct, which are formulated to govern behavioural patterns, namely the behaviour of individuals, groups and entities in society. ${ }^{3}$ Thus, the role of law in the context of this study is to underscore its significance and essence in terms of regulating energy resource activities, so as to promote and actualise access to affordable, reliable, sustainable and efficient modern energy for all. ${ }^{4}$ Law is certainly an instrument of social engineering, positive change and dynamic progress in society, which serves the strategic role of regulating (i.e., governing) 5 energy resources operations to stimulate realisation of the dream of the entire global community to engender effective energy resource operations, towards providing efficient and sustainable delivery of energy services to all societies and individuals, including poor people residing in rural areas of developing countries, by 2030. This is the target year agreed upon in the UN system and proclaimed by the UN, regarding delivery of sustainable modern energy services to all around the globe. ${ }^{6}$

However, although law is significant and inevitable in terms of governing behavioural patterns in society, it still remains an unresolved necessity in developing countries, which are suffering from the disease called energy poverty. ${ }^{7}$ This is so because energy poverty-stricken developing countries like Nigeria are yet unable to fully and gainfully utilise law or reluctant to do so, to address their lingering problems and challenges associated with ensuring effective and sustainable energy resource operations, towards efficient delivery of energy services for overall public good. It is in this kind of situation that law may be considered as a victim of bad governance in developing countries. Moreover, law and public good, certainly anything associated with

Company, The State and Underdevelopment of Nigeria's Niger Delta: A Study in Environmental Degradation (Africa World Press 2006); United Nations Environment Programme [UNEP], Environmental Assessment of Ogoniland (UNEP 2011).

1 R. Norman, The Moral Philosophers: An Introduction to Ethics (Oxford University Press 1998); H. LaFollette (ed), Ethics in Practice: An Anthology (Blackwell Philosophy Anthologies) (Blackwell Publishing 2007/John Wiley \& Sons 2014); M. Albertzart, Moral Principles (Bloomsbury Ethics) (Bloomsbury Academic 2014); J. Sacks, Morality: Restoring the Common Good in Divided Times (Hodder \& Stoughton 2020).

${ }^{2}$ Goal 7, UN Sustainable Development SD Goals (UNSDGs), captioned 'affordable and clean energy', which is designed to ensure access to affordable, reliable, sustainable and modern energy for all (described as 'sustainable energy for all' [SEforALL]) by 2030 (the target year proclaimed by the UN); homepage of Sustainable Energy for All (SEforALL) <https://www.seforall.org/> Accessed 27 April, 2020; Y. Omorogbe and A. O. Ordor (eds), Ending Africa's Energy Deficit and the Law: Achieving Sustainable Energy for All (Oxford University Press, 2018); A. Adenikinju et al (eds) (n4); E. T. Bristol-Alagbariya, lecture slides, 'Energy, Petroleum, Business Law, Policy and Regulations and Ethics', Course Code: PEEM 811/12, Emerald Energy Institute for Petroleum, Energy Economics, Policy and Strategic Studies (EEI), University of Port Harcourt, NIGERIA; E. T. BristolAlagbariya, lecture slides, 'The Economics of Energy and the Environment', Course Code:PEEM705, EEI, University of Port Harcourt, NIGERIA.

${ }^{3}$ E. T. Bristol-Alagbariya, 'Nigeria: The Role of Law in Nation-building' (2016) 1 (1) UNIPORT Journal of Public Law, 117-119; B. A. Garner (ed), Black's Law Dictionary (West Group 1999), 889-890; Cambridge Dictionary, 'law'<https://dictionary.cambridge.org/dictionary/english/law>; Oxford Dictionaries Online, 'law' $<$ http://www.oxforddictionaries.com/definition/english/law $>$ all Accessed 27 April, 2020.

${ }^{4}$ Goal 7, UN Sustainable Development SD Goals (UNSDGs), captioned 'affordable and clean energy'; UN, 'Sustainable Development Goals: About the Sustainable Development Goals' $<$ https://www.un.org/sustainabledevelopment/sustainable-development-goals/>; UN Sustainable Development Goals Knowledge 'Sustainable Development Goals' $<$ https://sustainabledevelopment.un.org/?menu=1300 $>$; homepage of Sustainable Energy for All (SEforALL)

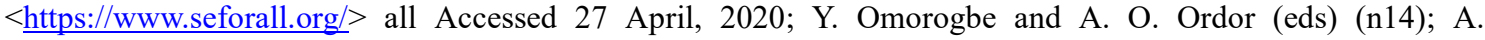
Adenikinju et al (eds) (n4).

${ }^{5}$ E. T. Bristol-Alagbariya (2016 [n15]), 117-119; B. A. Garner (ed) (n15), 889-890; c/f J. R. Sutton, Law/Society: Origins, Interactions, and Change (Pine Forge Press 2001).

${ }^{6}$ Goal 7, UN Sustainable Development SD Goals (UNSDGs), captioned 'affordable and clean energy'; UN, 'Sustainable Development Goals: About the Sustainable Development Goals' (n16); UN Sustainable Development Goals Knowledge Platform, (n16); homepage of Sustainable Energy for All (SEforALL) (n14).

${ }^{7}$ Y. Omorogbe and A. O. Ordor (eds) (n14), 5, 12-13, 131, 162, 209, 377, 380-381 and 384; A. Adenikinju et al (eds) (n4), 538-561. 
overall public good, such as all-embracing wellbeing of people, are victims of bad political leadership and in effect bad governance in developing countries, exemplified by countries like Nigeria, which are suffering from energy poverty. ${ }^{1}$ Whereas this is the case in developing countries, in the advanced countries, where political leaders endeavour to uphold the duties and obligations of government that are enshrined in the social contract of governance between government and the governed, ${ }^{2}$ such leaders are selflessly working to deliver government social responsibility (GSR), ${ }^{3}$ embedded in good governance (GG), ${ }^{4}$ so as to cater for the security and wellbeing of their people, as well as all-embracing prosperity, advancement and SD of their countries. ${ }^{5}$

The study would thus explore the nexus between energy poverty and bad governance. It would examine the connection between energy poverty and the multifaceted, multi-dimensional, versatile and all-encompassing negative consequences of bad governance on citizens, humanity at large and entire fabric of developing countries suffering from bad governance, such as Nigeria.

The study would also examine the link between natural law (associated with morality) and good laws. Consequently, given the qualitative nature of good laws and their relationship with morality, the study would make a case to promote natural law (and its school of thought), as opposed to the positive law theory (and its school of thought). The study would then establish the potential of natural law as the bedrock of virtue and GG and thus a veritable, necessary, crucial, strategic and inevitable tool in the march of countries and peoples around the world as well as the entire global community towards SD. ${ }^{6}$

\footnotetext{
${ }^{1}$ Ibid.

2 J. Rousseau, The Social Contract (Wordsworth Classics of World Literature) (Wordsworth Editions 1998); J. Rousseau, The Social Contract or Principles of Political Right (Aziloth Books 2011); M. Lessonoff (ed), Social Contract Theory (Basil Blackwell 1990); McCombs School of Business, 'Social Contract Theory' $<$ https://ethicsunwrapped.utexas.edu/glossary/social-contract-theory $>$; G. A. Oguntade, 'The Social Contract: Which Way Nigeria?' < https://thenationonlineng.net/social-contract-way-nigeria/>; both Accessed 27 April, 2020; K. Nweke and J. O. Nkwede, 'The Nigerian State and Hobbes' Social Contract Theory: An Albatross around the Collective Will of the People' [2019] 152 (3) European Journal of Scientific Research, 304-321; E. T. Bristol-Alagbariya, Governance Towards Sustainable Development in Nigeria: The Role of Strategic Assessment of Decisions \& Actions (CEPMLP/DUP 2013), 44-45, 55, 59-60, 64-65, 111-112, 155, 249 - 250, 258, 289 and 292; The Preamble and Section 14 (2) (b) of the 1999 Constitution of the FRN (CFRN) (as amended); which provides that the security and welfare of the people are the primary purposes of government. Section 14 of the Constitution is captioned 'The Government and the People'.

${ }^{3}$ E. T. Bristol-Alagbariya, 'Sustainable Development: A Soft Law Concept Transforming SD-Oriented Initiatives of the UN System into Hard Law Instruments in UN Member-states and Promoting Partnerships around the Globe' [2020] 94 Journal of Law, Policy and Globalization, 40, 49 and 50; E. T. Bristol-Alagbariya (2013 [n21]), 16-17 and 331.

${ }^{4}$ UN, 'Meetings Coverage and Press Releases: Good Governance Essential to Development, Prosperity, Peace Secretary-General Tells International Conference, Press Release SG/SM/6291/DEV/2166' $<$ https://www.un.org/press/en/1997/19970728.SGSM6291.html> Accessed 27 April, 2020, where Seventh UN Secretary-General (1 January, 1997 - 31 December, 2006), Kofi Annan, proclaimed that 'good governance and sustainable development are indivisible'; E. T. Bristol-Alagbariya (2013 [n21]), xxxvii-xxxviii, 46-49 and 272393.

${ }^{5}$ Ibid; WCED (n2), x-23, particularly 9; E. T. Bristol-Alagbariya (2010 [n11]), 75-82 and 329-337; K. Ginther et al (eds), Sustainable Development and Good Governance (Martinus Nijhoff Publishers 1995); G. Ayre and R. Callway (eds), Governance for Sustainable Development: A Foundation for the Future (Earthscan 2005); H. Clark, The Importance of Governance for Sustainable Development (The Institute of Southeast Asian Studies [ISEAS] Publishing 2012); T. Edoh and T. Wuam (eds), Democracy, Leadership And Accountability in PostColonial Africa: Challenges And Possibilities: Essays in Honour of Professor Akase Paul Sorkaa (Aboki Publishers 2009); T Wuam and T. N. Sunday (eds), Governance and Economic Development in the Fourth Republic (Aboki Publishers 2010); T. Jackson (2009 [n3]); T. Jackson (2011 [n3]); P. Bartelmus, Sustaining Prosperity, Nature and Wellbeing; What Do the Indicators Tell Us? (Routledge 2018).

${ }^{6}$ E. T. Bristol-Alagbariya, 'Natural Law as Bedrock of Good Governance: Reflections on Alagbariya, Asimini and Halliday-Awusa as Selfless Monarchs towards Good Traditional Governance and Sustainable Community Development in Oil-rich Bonny Kingdom' [2020] 10 (3) Developing Country Studies, 63-92; M. Decleris, The Law of Sustainable Development: General Principles: A Report Produced for the European Commission (European Commission 2001); M. C. Segger and A. Khalifan, Sustainable Development Law: Principles, Practices, and Prospects (Oxford University Press 2004).
} 


\section{Law and Ethics}

A discourse on law and ethics may commence with the description of law and then a consideration of ethics, as morals, particularly morality-in-action. ${ }^{1}$ These may be followed by an analysis of the relationship between law and ethics. ${ }^{2}$

\subsection{Law}

Law may be described as the enforceable body of rules of a particular country, group or area of activity. It is a body or system of binding modes of conduct, such as principles, precepts, rules, tenets and regulations, formulated to govern behavioural patterns, namely the behaviour (actions and omissions) of individuals, groups and entities in society. ${ }^{3}$ As domestic law (the law of a sovereign state), it is a system of modes of conduct, which is formulated and enforced in the state, to regulate the behaviour of citizens, other people, entities and groups within the jurisdiction of the state, to promote and achieve order, peace and GG. ${ }^{4}$ Law shapes behavioural patterns of humans and society and thereby serves as the instrument that regulates the activities of government, relations between government functionaries and the people (citizens and residents) of sovereign states, as well as governs relations between and among individuals, groups, entities and society at large within the state. ${ }^{5}$ A breach of the law attracts deterrent measures, such as caution, award of damages and imposition of penalty or sanction, such as payment of fine and/or committal to imprisonment. ${ }^{6}$

\subsection{Ethics as Morals (Morally Good Actions)}

We consider that ethics relate to morals, such as moral lessons, norms, principles, guidelines and standards, which determine the rightful or wrongful nature of a particular conduct. ${ }^{7}$ As distinct from bad behaviours, ethics are about moral behaviours that conform to accepted standards of good behaviour in society. ${ }^{8}$ Ethics and morals are synonymous because ethics are moral (i.e., good) values and the lessons arising from same in action. In other words, whereas morals are mere norms, values or lessons, ethics are norms, values or lessons put into action or practice. Ethics imply practising moral norms, values or lessons. Ethics may therefore be referred to as morals-in-action (morality-in-action: morally good action or practice). ${ }^{9}$

\subsection{The Relationship between Law and Morality and hence Ethics}

The subject-matter of relationship between law and morality and hence ethics brings our discourse to the parlance of jurisprudence, which is commonly considered as the theory or philosophy of law, otherwise

${ }^{1}$ E. T. Bristol-Alagbariya, lecture slides, 'Energy, Petroleum, Business Law, Policy and Regulations and Ethics', Course Code: PEEM 811/12 (n14).

${ }^{2}$ Ibid.

${ }^{3}$ E. T. Bristol-Alagbariya (2016 [n15]), 117.

${ }^{4}$ Ibid.

${ }^{5}$ Ibid, 117-119; B. A. Garner (ed) (n15), 889-890.

$6 \mathrm{Ibid}$; Cambridge Dictionary, 'law' $<$ https://dictionary.cambridge.org/dictionary/english/law $>$; Oxford Dictionaries Online, 'law' < http://www.oxforddictionaries.com/definition/english/law $>$ all Accessed 27 April, 2020.

${ }^{7}$ S. Kagan, Normative Ethics: Dimensions of Philosophy Series (Routledge 1998); IGI Global, 'What is Ethics' $<$ https://www.igi-global.com/dictionary/ethics-in-higher-education/10276 $>$; $\quad$ BBC, 'Ethics: A General Introduction' <http://www.bbc.co.uk/ethics/introduction/intro 1.shtml>; J. Fieser, 'ETHICAL THEORY: From Moral Issues that Divide Us' $<$ https://www.utm.edu/staff/jfieser/class/160/1-ethical-theory.htm $>$ all Accessed 27 April, 2020; R. Norman (n13); H. LaFollette (ed) (n13); M. Albertzart (n13).

${ }^{8}$ B. Herman, Morality as Rationality: A Study of Kant's Ethics (Routledge Library Editions: Kant) (Routledge 2017); Salem Press, Ethics: Questions \& Morality of Human Actions (H.W. Wilson Publishing Co. 2019); Knowledge Base, 'Moral Practices - Ethical Standards - Right and Wrong Behavior' $<$ https://www.basicknowledge101.com/categories/morality.html $>$ Accessed 27 April, 2020.

9 J. Kemp, Reason, Action and Morality: International Library of Philosophy and Scientific Method (Humanities Press 1964); J. Kemp, Reason, Action and Morality: Routledge Library Editions; Ethics (Routledge 2020); W. Quinn, Morality and Action: Cambridge Studies in Philosophy (Cambridge University Press 2003); B. Sachs, Explaining Right and Wrong: A New Moral Pluralism and Its Implications (Routledge Studies in Ethics and Moral Theory (Routledge 2017); G. Spielthenner, 'What Makes Actions Morally Good?' [2005] VII (1) Etica \& Politica/Ethics \& Politics, 1-13; Stanford Encyclopedia of Philosophy, 'The Definition of Morality' $<$ https://plato.stanford.edu/entries/morality-definition/>; M. King (Routledge Encyclopedia of Philosophy), 'Ethics and Action' <https://www.rep.routledge.com/articles/thematic/ethics-and-action/v-1>; J. Gordon (Internet Encyclopedia of Philosophy), 'Modern Morality and Ancient Ethics' $<$ https://www.iep.utm.edu/anci$\underline{\bmod />}$ all Accessed 27 April, 2020. 
called legal philosophy. ${ }^{1}$ This subject-matter may, in other words, be associated with certain theories of law as well as their accompanying schools of thought (legal philosophy), namely the theory of natural law (and its school of thought), as opposed to the positive law theory (and its school of thought). ${ }^{2}$

The natural law theory, which emphasises the divine origin of law and leadership as well as the moral content law, posits that law consists of a set of universal moral principles in accordance with nature. ${ }^{3}$ This theory, which espouses the dynamic and effectual relationship between law and morality vis-à-vis the objective moral basis or order of good human actions, ${ }^{4}$ postulates that moral principles, rules and standards should or ought to be characteristically embedded in laws governing human societies, such as sovereign states. ${ }^{5}$

On the other hand, the positive law theory, which is essentially a reaction to the natural law school of thought, considers law as an obligatory mode of conduct made by human authority, ${ }^{6}$ advocates that law is a collection of valid rules, commands or norms that may lack moral content. ${ }^{7}$ The positive law theory argues that natural law theory exaggerates the relationship between law and morality presupposes that there is no need to use reason, morality, justice or fair-play to determine the nature and validity of law. It contends that law is the rule, directive or command of a sovereign or sovereign state, the breach of which attracts sanction. ${ }^{8}$

\section{Ethics Associated with Energy Resources Development Operations}

It may be pertinent to discuss energy resources, before proceeding to give account of the ethics associated with energy resources development operations.

\subsection{Energy Resources: Sources of Energy Supply}

Energy resources may be described as all forms of fuel used by the humans for heating, generation of electrical energy and other forms of energy conversion processes. These resources are therefore the sources from which energy is derived, produced and supplied for the use of human beings and overall benefit of society. ${ }^{9}$ They are necessary for the daily sustenance and survival of humans and society as a whole. ${ }^{10}$ They are inevitable for the development, advancement and overall prosperity of the human race and society as a whole. ${ }^{11}$ Energy resources enhance the functionality, viability and vitality of other sectors to the economy of a country. ${ }^{12}$ The

1 Legal Information Institute, Cornell Law School, Jurisprudence' $<$ https://www.law.cornell.edu/wex/jurisprudence $>$ Accessed 27 April, 2020.

2 R. Pound, 'Theories of Law' [1912] 22 (2) Yale Law Journal, 114-150; T. Abate, 'Major Theories of Law' $<$ https://www.abyssinialaw.com/about-us/item/479-major-theories-of-law> Accessed 27 April, 2020.

${ }^{3}$ B. A. Garner (ed) (n15), 1049-1050.

${ }^{4}$ D. Westberg, 'The Relation between Positive and Natural Law in Aquinas' [1994-1995] 11 (1), Journal of Law and Religion, 1-22.

${ }^{5}$ M. H. Kramer, Where Law and Morality Meet (Oxford University Press 2004); A. Gomez-Lobo, Morality and the Human Goods: An Introduction to Natural Law Ethics (Georgetown University Press 2001); J. Budziszewski, Written on the Heart: The Case for Natural Law (InterVarsity Press 1997); C. E. Rice, 50 Questions on the Natural Law: What It Is and Why We Need It (Ignatius Press 1999); L. L. Weinreb, Natural Law and Justice (Harvard University Press 1990); C. Roosevelt, The Science of Government, Founded On Natural Law (Nabu Press 2014); J. D. Breshears, Natural Law: The Moral Foundation for Social and Political Civility (CentrePointe Publishing 2016); R. F. L. Girard, Hugo Grotius: Natural Law and Social Contract Theory (CreateSpace Independent Publishing Platform 2014); P. E. Sigmund, Natural Law in Political Thought (University Press of America 1981); C. F. Alford, Narrative, Nature, and the Natural Law: From Aquinas to International Human Rights (Palgrave Macmillan 2010); J. Finnis, Natural Law \& Natural Rights (Oxford University Press 2011).

${ }^{6}$ B. A. Garner (ed) (n15), 1182.

${ }^{7}$ Internet Encyclopedia of Philosophy, 'Legal Positivism' < https://www.iep.utm.edu/legalpos/> Accessed 27 April, 2020.

${ }^{8}$ P. Eleftheriadis, 'Law and Sovereignty' [2010] 29 (5), Law and Philosophy, 535-569; J. B. Murphy, The Philosophy of Positive Law: Foundations of Jurisprudence (Yale University Press 2005); P. Minkkinen, Sovereignty, Knowledge: A Glasshouse Book (Routledge 2009); R. Jackson, Sovereignty: The Evolution of an Idea (Key Concepts Series) (Polity 2007); Law Teacher, 'Legal Positivism' < https://www.lawteacher.net/freelaw-essays/jurisprudence/legal-positivism.php>; Legal Dictionary, 'Definition of Positive Law' $<$ https://legaldictionary.net/positive-law/> both Accessed 27 April, 2020.

9 R. L. Bradley (Jnr) and R. W. Fulmer (n1), 4.

${ }^{10}$ Ibid, WCED (n2), 168, 171 and 181-189.

${ }^{11} \mathrm{Ibid}$; D. D. Dears (n3); H. H. Schobert (n3), 1-10.

${ }^{12}$ A. Adenikinju et al (eds) (n4), 27-28. 
significance of energy resources to humans and society at large cannot be overemphasised. Thus, the ability of humans to harness energy resources is arguably the most important step in the history of human civilisation. ${ }^{1}$

The sources of global energy supply may be considered in two broad categories, namely non-renewable and renewable resources. ${ }^{2}$ In between these two categories of energy resources, are solar (trapped/stored solar), wood and nuclear, ${ }^{3}$ which may in certain cases or circumstances be considered as non-renewable and renewable energy resources. This study will however concentrate on non-renewable and renewable energy resources.

\subsubsection{Non-Renewable Energy Resources}

Non-renewable energy resources are those derived from sources that will run out or cannot be replenished in foreseeable future of human timescale or during the lifetime of many humans. ${ }^{4}$ They take millions of years to form and their reserves are depleted faster than new ones are formed. Non-renewable category of energy resources are mainly fossil fuels such as coal, oil and natural gas. Fossil Fuels as energy resources may simply be referred to as 'fossilized energy'. Fossil means the remains or impression of a prehistoric plant or animal embedded in rock and preserved in petrified form. Fossil fuels are the remains of plants and animals that were decomposed and buried deep in the Earth's crust millions of years ago. The theory is that fossil fuels are formed from the fossilised remains of dead plants and animals which remains were exposed to heat and pressure in the Earth's crust over millions of years. ${ }^{5}$ Different types of fossil fuels are formed, depending on what combination of organic matter was present, how long it was buried and what temperature and pressure conditions existed as time passed during the period (of over millions of years). ${ }^{6}$ Fossil fuels constitute most of global nonrenewable energy resources. ${ }^{7}$

From the era of industrial revolution in Britain in the $18^{\text {th }}$ Century, up to the $2^{\text {nd }}$ half of the $20^{\text {th }}$ Century, fossil fuels were the major forms of the energy resources around the world. Britain led the world into industrialisation in the $18^{\text {th }}$ Century, when machines were powered by coal, following which electricity produced from burning coal, began to take over from manual labour. ${ }^{8}$

Fossil fuels are valuable sources of energy resources, which have certain advantages, ${ }^{9}$ even over renewable energy resources. They are relatively inexpensive to extract. Fossil fuels, such as coal, oil and gas, are abundant such that they are relatively cheaper and readily available. ${ }^{10}$ Also, very large amounts of electricity can be generated from fossil fuels. They can also be stored, piped, or shipped anywhere in the world. ${ }^{11}$

Nevertheless, fossil fuels have enormous disadvantages, which make them unsustainable in the ongoing age of SD. ${ }^{12}$ Fossil fuels are disadvantageous because they are not environmentally friendly and thus have enormous environmental costs, such as the emission of greenhouse gases such as carbon dioxide, which cause climate change and global warming, which occasion depletion of the ozone layer in the atmosphere and other adverse effects on aquatic and terrestrial environments and their respective ecosystems, ${ }^{13}$ as well as public health. ${ }^{1}$

\footnotetext{
${ }^{1}$ World Energy Council (WECouncil) (n5).

${ }^{2}$ A. Adenikinju et al (eds) (n4), 223 and 417-500; College of Agricultural Sciences, The Pennsylvania State University, 'Renewable and Nonrenewable Resources' < $\underline{\text { https://extension.psu.edu/renewable-and-nonrenewable- }}$ resources $>$ Accessed 27 April, 2020.

${ }^{3}$ Principle 26, Stockholm Declaration on the Human Environment, 1972, on nuclear and other weapons of mass destruction.

${ }^{4}$ National Geographic Society, 'Non-renewable Energy: Non-renewable energy comes from sources that will eventually run out, such as oil and coal' $<$ https://www.nationalgeographic.org/encyclopedia/non-renewableenergy/> Accessed 27 April, 2020.

${ }^{5}$ Bobo's Little Brainiac Books, What Are Fossil Fuels? How Oil Is Made! - Science for Kids (Sunshine in My Soul Publishing 2016).

6 US Department of Energy, 'Fossil' <https://www.energy.gov/science-innovation/energy-sources/fossil > Accessed 27 April, 2020

${ }^{7}$ O. C. Kopp (Encyclopædia Britannica) (n7); Environmental and Energy Study Institute (EESI) (n7).

${ }^{8}$ Ibid; D. D. Dears (n3), particularly 5-7.

${ }^{9}$ A. Epstein, The Moral Case for Fossil Fuels (Portfolio Penguin Group 2014).

${ }^{10}$ Ibid.

${ }^{11}$ National Geographic Society (n50).

12 J. F. Sachs, The Age of Sustainable Development (University of Columbia Press 2015); J. Blewitt, Understanding Sustainable Development (Earthscan 2008).

${ }^{13}$ J. M. Halley, 'Comparing Aquatic and Terrestrial Variability: At What Scale Do Ecologists Communicate?' [2005] 304, Marine Ecology Progress Series, 274-280; Blue Planet Education about Our World, 'A Local Ecosystem: Abiotic Characteristics of Aquatic and Terrestrial Environments'
} 


\subsubsection{Renewable Energy Resources}

Renewable energy resource is an energy source that can regenerate and can replenish itself indefinitely. ${ }^{2}$ It is a source of energy that is derived from natural processes that are replenished constantly. It is a source of energy that is naturally replenish-able or replenished on a human timescale. Renewable energy resource is a source of energy that is derived from natural processes and can regenerate itself indefinitely. Such resources are thus naturally replenish-able or constantly replenished on a human timescale. Renewable energy resources include the following five major ones; namely sun, wind, water (falling water or fast running water), biomass (bio energy) and geothermal energy resources. Renewable energy often provides energy in such forms as electricity generation, air and water heating as well as cooling, transportation, and rural (off-grid) energy services. They are also sometimes referred to as alternative energy resources. ${ }^{3}$ These alternatives are intended to address concerns about non-renewable energy resources such as fossil fuels. ${ }^{4}$

There are several advantages of renewable energy resources. ${ }^{5}$ These include the fact that they are spread over wide geographical localities of the globe. ${ }^{6}$ This is in contrast with other energy sources that are concentrated in a limited number of countries, where the resources associated with them are extracted in rural and remote areas such as developing countries.

While many renewable energy projects are large-scale, renewable technologies are also suited to rural and remote areas and developing countries, where energy is often crucial in human wellbeing. Renewable energy systems are rapidly becoming more efficient and cheaper, and thus could, for example, make hydrogen become cheaper than gas. Their share of total energy consumption is increasing. It is being projected that the consumption of coal and oil would decline in the near future, due to increased availability of renewable energy resources and natural gas. Renewable energy projects can also bring socio-economic benefits to areas where they are sited or located, away from cities, large urban centres and capital cities. These benefits may be from the increased access to socio-economic amenities, increased use of services in the locality as well as tourism potentials. Also, renewable energy resources have minimal negative impact(s) on the environment than nonrenewable energy resources like fossil fuels. Besides, in terms of relatively improved public health, generating electricity from renewable energy rather than fossil fuels offers significant public health benefits. However, health challenges, such as breathing problems, neurological damage, heart attacks and cancer, have been identified where air pollution and water pollution are occasioned through emissions from coal and natural gas plants. ${ }^{7}$ Besides, in areas where existing electricity grid (distribution system) does not extend to, especially in

$<\underline{\text { http://www.blueplanet.nsw.edu.au/ale--abiotic-characteristics-of-aquatic-and-terrestrial-environments/.aspx }>}$ Accessed 27 April, 2020.

${ }^{1}$ Harvard Chan T. H. Chan School for Public Health, 'Costs and Health Co-Benefits for a U.S. Power Plant Carbon Standard' < https://www.hsph.harvard.edu/c-change/subtopics/fossil-fuels-health/>; Climate Nexus, 'The Localized Health Impacts of Fossil Fuels: From extraction to combustion, fossil fuel operations put human health at serious risk' $<$ https://climatenexus.org/climate-issues/health/the-localized-health-impacts-of-fossilfuels/>; Union of Concerned Scientists, 'The Hidden Costs of Fossil Fuels: The true costs of coal, natural gas, and other fossil fuels aren't always obvious-but their impacts can be disastrous'

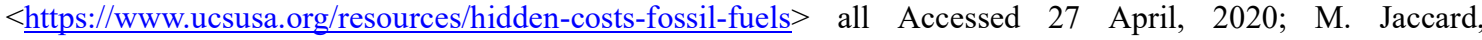
Sustainable Fossil Fuels: The Unusual Suspect in the Quest for Clean and Enduring Energy (Cambridge University Press 2006); D. Helm, Burn Out: The Endgame for Fossil Fuels (Yale University Press 2017).

${ }^{2}$ B. Usher, Renewable Energy: A Primer for the Twenty-First Century (Columbia University Press 2019); C.

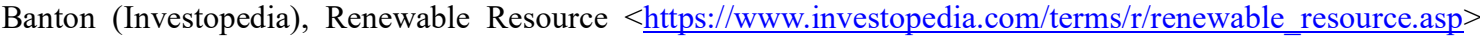
Accessed 27 April, 2020; WCED (n2), 169 and 171.

${ }^{3}$ R. DeGunther, Alternative Energy for Dummies (Wiley Publishing Inc. 2009).

${ }^{4}$ Y. Omorogbe and A. O. Ordor (eds) (n14), 5, 12-13, 131, 162, 209, 377, 380-381 and 384; M. Kuperberg, Energy Future: Fossils and Beyond (Dekel Publishing House/Samuel Wachtman's Sons Inc. 2017); D. Elliott, Renewables: A Review of Sustainable Energy Supply Options (IOP Publishing 2013).

5 Union of Concerned Scientists, 'Benefits of Renewable Energy Use' $<$ https://www.ucsusa.org/resources/benefits-renewable-energy-use $>$; Conserve Energy Future, 'What is Renewable Energy?' <https:/www.conserve-energy-future.com/advantages-and-disadvantages-of-renewableenergy.php $>$; Terna Energy (GEK Terna Group), Advantages of Renewable Energy Sources (RES) $<\underline{\text { http://www.terna-energy.com/company/The-Sector/Advantages-Of-RES/>; }}$

A. Mahmoud, 'The Advantages and Disadvantages of Renewable Energy' $<$ https://www.linkedin.com/pulse/advantages-disadvantages-renewable-energy-ashraf-mahmoud $>$ all Accessed 27 April, 2020.

${ }^{6}$ Y. Omorogbe and A. O. Ordor (eds) (n14), 20-21.

7 Union of Concerned Scientists, 'Environmental Impacts of Natural Gas'

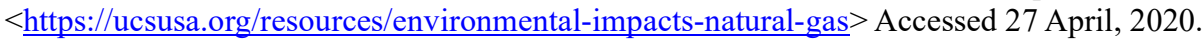


areas inhabited by poor people, renewable energy features as their source of energy supply. ${ }^{1}$ Renewable energy services also promote peace, security and GSR, in developing countries, such as those of Africa, where the domains of poor citizens and residents are not connected to existing electricity grid, as well as areas plagued by epileptic electricity (power) supply. ${ }^{2}$

Conversely, there are certain disadvantages of renewable energy resources. One disadvantage of renewable energy is that it is difficult to generate. It is still difficult to generate large quantities of electricity through renewable energy resources than those being generated through traditional fossil fuels energy sources. This implies a need for development of more renewable energy facilities or a reduction of the rate of energy currently being used to support and sustain humans and society on a daily basis. Another disadvantage of renewable energy sources is the dependence of supply. Renewable energy often relies on the weather for its source of power. For instance, hydro generators need rain to fill dams to supply flowing water. Hydro power may need rain as well as water supply from a nearby river source(s). Accordingly, wind turbines need wind to turn their blades, while solar collectors need clear skies and sunshine to secure heat for purposes of electricity supply. When these resources are unavailable, it is impossible to derive energy resources, namely power, from the renewable energy resources, such as hydro and wind power resources. Essentially, reliance of renewable energy facilities on weather conditions to generate energy supply may be unpredictable and inconsistent. Besides, current renewable energy technology facilities are more expensive than traditional fossil fuel power generation schemes. Renewable energy schemes also involve new forms of technology that are relatively more expensive (capital cost) than those of traditional fossil fuel generation schemes. It has indeed been observed that about the biggest disadvantage of renewable energy is the relatively higher cost of their facilities or schemes than those of fossil fuels, which continue to prevent higher utility of clean energy resources, as compared to the nonrenewable resources of energy. Essentially, harnessing effective renewable energy such as electricity supply depends on cost and efficiency of the technology. ${ }^{3}$

Generally, non-renewable energy and renewable energy resources have negative environmental consequences. ${ }^{4}$ For instance, solar power has certain negative environmental impacts. The potential environmental impacts associated with solar power, such as land use and habitat loss, water use and the use of hazardous materials in manufacturing purposes, may vary greatly, depending on the technology involved. For instance, there are two broad categories (photovoltaic [PV] solar cells or concentrating Solar Thermal Plants $[\mathrm{CSP}]$ ), which have their distinct technical features and environmental impacts associated with them, regarding power generation. ${ }^{5}$ Besides, wind power may cause global warming. The deployment of large scale wind power may occasion temperature rise. Also, the direct climate change impacts of wind power are instant, while the benefits of reduced emissions accumulate slowly. Therefore, in relation to fossil fuels, such as coal and gas, wind farms are prone to cause more negative environmental consequences than had been previously considered by many. ${ }^{6}$ Furthermore, there are yet untapped renewable energy resources, ${ }^{7}$ towards energy efficiency ${ }^{8}$ and a sustainable future. ${ }^{9}$

Consequently, a pragmatic solution to the problem of energy security ${ }^{10}$ and energy efficiency around the world is for consumers to have a cost effective option, by balancing the degree of consumption of nonrenewable and renewable energy resources. Humans, as consumers of energy for our wellbeing and overall wellbeing of society, are also required to boost energy security and energy efficiency by promoting international benchmarked standards and practices of energy resources development operations and as well as ensuring proper, effective and non-destructive use of energy resources, by maximising the benefits being derived from

${ }^{1}$ Y. Omorogbe and A. O. Ordor (eds) (n14), 20-21.

${ }^{2}$ Ibid, 21.

${ }^{3}$ D. D. Dears (n3); World Nuclear Association, 'Renewable Energy and Electricity' < $\underline{\text { https: } / / \text { www.world- }}$ nuclear.org/information-library/energy-and-the-environment/renewable-energy-and-electricity.aspx $>\quad$ Accessed 27 April, 2020; A. Mahmoud (n64).

${ }^{4}$ D. W. Pearce and R. K. Turner, Economics of Natural Resources and the Environment (The John Hopkins University Press 1990), 309-360; H. H. Schobert (n3), 270-273.

5 Union of Concerned Scientists, 'Environmental Impacts of Solar Power' $<$ https://www.ucsusa.org/resources/environmental-impacts-solar-power> Accessed 27 April, 2020.

${ }^{6}$ The Harvard Gazette, 'The down side to wind power: Wind farms will cause more environmental impact than previously thought' $<$ https://news.harvard.edu/gazette/story/2018/10/large-scale-wind-power-has-its-down-

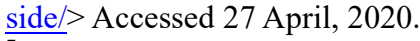

${ }^{7}$ WCED (n2), 192-196.

${ }^{8}$ WCED (n2), $196-200$.

${ }^{9}$ WCED (n2), 201-202.

${ }^{10}$ Y. Omorogbe and A. O. Ordor (eds) (n14); S. C. Dike, Energy Security: The Case of Nigeria and Lessons from Brazil, Norway and the UK (Pearl Publishers 2015). 
these resources and thereby minimising the costs (burdens) involved. These require promoting and maintaining efficient life-cycle of energy resources operations. ${ }^{1}$ In turn, these require reducing emphasis on non-renewable energy resources, while investing more in renewable and cleaner energy resources, to ensure access to affordable, reliable, sustainable and efficient modern energy for all (belonging to the present generation) without compromising same for future generations. ${ }^{2}$

\subsection{Ethics Associated with Energy Resources Development towards Sustainable Energy Resources Development Operations}

So far, the foregoing sub-headings have deliberated on certain key terms and aspects of this study. These are ethics, law and the relationship between law and ethics, as well as sources of energy supply, namely non-renewable energy resources and renewable energy resources, including the advantages and disadvantages of these two basic categories of energy resources. Energy resources are discussed in relation to the prevailing problem of energy security and energy efficiency, which are associated with access to affordable, reliable, sustainable and efficient modern energy for all, aimed at achieving Goal 7 of the UNSDG, by $2030 .{ }^{3}$ International benchmarked standards and practices of energy and major natural resources operations, including such standards and practices of energy resources development operations, underscore certain ethics, ethical issues or ethical conducts relating to these resources development operations, so as to promote SD.

Petroleum, a focal point of this study, is, as mentioned earlier, an example of fossil fuels. ${ }^{4}$ Petroleum resources are energy and major natural resources. These resources development operations are extractive industrial operations (EIOs), which have several negative effects, ranging from ecological and generic environmental effects to health, socio-economic and other numerous negative consequences. Thus, for well over six decades, there have been adverse consequences of petroleum development operations in oil-rich communities of the ethnic minority Delta region. These adverse consequences also affect other oil producing areas of Nigeria and the entire Nigerian nation.

We may therefore proceed to give an overview of the problems associated with petroleum development operations in the entire Nigerian nation. Doing so, would provide a background to enable us outline and briefly discuss some of the ethics, ethical issues or morally good behaviours associated with energy resources development operations, using petroleum resources development operations in the country as examples. By and large, this overview will help showcase the significance of ethics in energy resources development operations, towards sustainable delivery of energy services to all, in the ongoing effort of the entire global community towards SD. ${ }^{5}$

\subsubsection{Overview of the Problems Associated with Petroleum Resources Development Operations in the Oil Producing Areas of Nigeria and the entire Nigerian Nation}

We consider it pertinent to examine this sub-heading in two divisions, namely (a) the problems associated with petroleum development operations in the oil producing areas of Nigeria and (b) the problems relating to petroleum development operations in the entire Nigerian nation, while noting that sub-heading (a) is a part and parcel of sub-heading (b).

\subsubsection{Problems Associated with Petroleum Resources Development Operations in the Oil Producing Areas of Nigeria}

The problems and challenges associated with petroleum resources development operations in Nigeria may first be considered in the context of the oil producing areas of the country, beginning with the oil-rich Niger Delta region, where these resources development operations commenced well over six decades ago (from the late 1950s). These problems are essentially the costs, adverse consequences and paradoxes of petroleum resources development operations in the country's oil producing areas. ${ }^{6}$

Petroleum development operations commenced in the oil-rich communities of the ethnic minority Delta region, sequel to commercial discovery of crude oil on Sunday, 15 January, 1956, at Otuabagi, in the British

\footnotetext{
${ }^{1}$ Y. Omorogbe and A. O. Ordor (eds) (n14); A. Adenikinju et al (eds) (n4); R. L. Bradley (Jnr) and R. W. Fulmer (n1).

${ }^{2}$ Goal 7, UN Sustainable Development SD Goals (UNSDGs), captioned 'affordable and clean energy'; homepage of Sustainable Energy for All (SEforALL) (n14).

${ }^{3}$ E. T. Bristol-Alagbariya, 'Environmental Assessment Law and Practice in Nigeria towards Achieving the UN Sustainable Development Goals (UNSDGs) in the Country: Cases of SDGs 13 and 17' [2019] 92 Journal of Law, Policy and Globalization, 67, 70-71 and 73.

${ }^{4}$ National Geographic Society (n9).

${ }^{5}$ Y. Omorogbe and A. O. Ordor (eds) (n14); J. F. Sachs (n58); J. Blewitt (n58).

${ }^{6}$ L. Barrera-Hernandez et al (eds), Sharing the Costs and Benefits of Energy and Resources Activity: Legal Change and Impact on Communities (Oxford University Press 2016).
} 
Colonial Oloibiri District of present-day Bayelsa State. In the context of the British Colonial District system in Nigeria, this discovery site was named the Oloibiri oilfield. The entire six Niger Delta (Southern ethnic minorities: South-South geopolitical zone of Nigeria) States, namely Rivers, Delta, Bayelsa, Akwa-Ibom, Edo and Cross-River States, are Nigeria's oil producing States. ${ }^{1}$

Few decades after the late 1950s, crude oil was also discovered in the communities of neighbouring states of the primordial Niger Delta region (otherwise called the ethnographic, geographic and historic ethnic minority Delta region of Nigeria). So far, further discoveries of crude oil had been made in the oil-rich communities of Abia and Imo States of the Igbo major ethnic group, and the oil-rich communities in Ondo State of the Yoruba major tribe.

Soon after the commencement of petroleum resources development operations in the oil producing communities of the oil-rich ethnic minority Delta region, the resources development operations began to generate adverse consequences on the environment, people and communities of the region. There have been decades of costs (burdens), negative effects and paradoxes of petroleum energy and major natural resources EIOs in the oil-rich ethnic minority Delta region of Nigeria, including other oil producing areas of the country.

We have already stated above that fossil fuels, such as coal, oil and gas, are not environmentally friendly. Petroleum energy and major natural resources EIOs in Nigeria are occasioning enormous costs, negative consequences and paradoxes in the oil-rich communities of the Delta region, described as the 'fossil fuel capital' of Nigeria. ${ }^{2}$ By and large, various costs, adverse effects and paradoxes of petroleum development operations in the Delta region and other oil-producing areas of Nigeria may be classified into environmental, socio-economic and political consequences. These adverse consequences include paradox of poverty and misery in the midst of plenty, lack of genuine engagement of the citizens and citizen-groups in the course of the resources development operations in their communal homelands. ${ }^{3}$ Other costs, adverse effects, paradoxes and challenges include ineffective development project-level environmental assessment, namely environmental impact assessment (EIA), lack of life-cycle assessment of petroleum development projects and absence of institutionalised strategic environmental assessment (SEA) in Nigeria ${ }^{4}$ as well as lack of just and equitable impact-benefits and impact-benefits agreements (IBAs). ${ }^{5}$ There is generally lack of IBAs or other forms of Good

${ }^{1}$ Section 1 (2) (b), Niger-Delta Development Commission (Establishment Etc.) (NDDC) Act, No. 6, Laws of the Federation of Nigeria (LFN) 2000, Cap N86 LFN 2004; Section 1, NDDC Act is captioned 'Establishment of the Niger-Delta Development Commission'; Section 4 of the Act, entitled 'Rotation of Office of Chairman of the Commission'; Section 30 of this Act, headed 'Interpretation', regarding the interpretation of the meaning of 'member states' and the interpretation of the meaning of 'oil'; Niger Delta Development Commission (Establishment, Etc.) (NDDC) Amendment Act, 2017.

${ }^{2}$ C. I. Obi, 'Oil Extraction, Dispossession, Resistance, and Conflict in Nigeria's Oil-Rich Niger Delta' [2010] 30 (1-2) Canadian Journal of Development Studies, 219-236.

3 D. S. P. Alamieyeseigha, 'The Environmental Challenge of Developing the Niger Delta' $<$ http://www.gasandoil.com/news/africa/dc25fd9a4f269db32cbd840c81556edb $>$ Accessed 5 October, 2019 ; E. J. Alagoa et al (eds), History Concourse 2011: The Niger Delta Environment as Resource and Reserve (Onyoma Research Publications 2012), 217-267; A. Ogbuigwe, Offended: Legal Issues in the Niger Delta Struggle (Anpez Centre for Environment and Development 1999), especially 2-43 and 187-193; A. A. Ikein (n6); R. Cui, Oil Multinationals in Nigeria Human Rights, Sustainable Development and the Law (Anchor Academic Publishing 2015); A. Manirabona and Y. V. Cárdenas, Extractive Industries and Human Rights in an Era of Global Justice: New Ways of Resolving and Preventing Conflicts (LexisNexis Canada 2019); O. Oluduro, 'Oil Exploitation and Human Rights Violations in Nigeria's Oil Producing Communities' [2012] 25 (2) Afrika Focus, 160-166; Wiwa v Shell Petroleum Development Company of Nigeria Limited (SPDC), 04 Civ. 2665, (SDNY); Wiwa et al. v Royal Dutch Petroleum Company, et al., Case No. 96 Civ. 8386 (KMW) (HBP) (Southern District of New York [SDNY]); Ken Wiwa et al. v Brian Anderson et al., Case No. 01 Civ. 1909 (KMV) (HBP) (SDNY); Kiobel v Royal Dutch Petroleum Company [2013] US 133 S Ct. 1659; Gbemre (Jonah Gbemre) v The Shell Petroleum Development Company Nigeria Ltd. \& 2 Ors [2005] FHC/B/CS/53/05).

4 E. T. Bristol-Alagbariya (2010 [n11]), 7, 137-146, 330 and 326-327; E. T. Bristol-Alagbariya (2013 [n21]), xxxiii, xxxvii, xxxix, xliii - xlvii, $35-49,62-63,71-72,265,267-268,276-280$ and $288-289$.

${ }^{5}$ K. Yaworsky, 'First Nations Consultation and Impact Benefit Agreements' $<\underline{\text { https://www.shk.ca/first-nations- }}$ consultation-impact-benefit-agreements/>; A. J. Wright (The Canadian Community Economic Development Network [CCEDNet]), 'Impact and Benefit Agreements: The Role of Negotiated Agreements in the Creation of Collaborative Planning in Resource Development' $<$ https://ccednet-rcdec.ca/en/toolbox/impact-and-benefitagreements-role-negotiated-agreements $>$; B. Gilmour and B. Mellett, 'The Role of Impact and Benefits Agreements in the Resolution of Project Issues with First Nations' $<$ https://www.albertalawreview.com/index.php/ALR/article/view/71> all Accessed 27 April, 2020; B. Gilmour and B. Mellett, 'The Role of Impact and Benefits Agreements in the Resolution of Project issues with First 
Neighbour Agreements between oil companies and oil producing communities; rather, there is a regime of various forms of memorandum of understanding $(\mathrm{MoU})$ between oil companies and oil producing communities, which are causing misunderstanding, confusion and crises in the communities. ${ }^{1}$ There are also such adverse consequences of these resources development operations as negative health impacts, ${ }^{2}$ human rights abuses and violations, ${ }^{3}$ oil pollution, ${ }^{4}$ degradation, devastation and despoliation of the environment, ecology and ecosystems, as well as deterioration of ecosystem services in the oil-rich Delta region ${ }^{5}$ and other oil producing areas of Nigeria, ${ }^{6}$ thereby undermining the general wellbeing of the oil-rich communities, citizens and future generations of the communities. Yet other costs, adverse effects and challenges are community crises, ${ }^{7}$ which include violent conflicts aggravated by youth restiveness and insurgency, ${ }^{8}$ as well as insecurity of lives and property ${ }^{9}$ arising from the crises in the oil-rich communities of the ethnic minority oil-rich Delta region. ${ }^{10}$ These paradoxes associated with unsustainable petroleum resources development operations in the Niger Delta region made the Delta region to become endangered and crises-ridden, justifying the region's historic 'resource control'

Nations' [2013] 51 (2) Alberta Law Review, 385-400; S. A. Kennett, A Guide to Impact and Benefits Agreements (University of Calgary 1999); C. O'Faircheallaigh, 'Community Development Agreements in the Mining Industry: An Emerging Global Phenomenon’ [2013] 44 (2) Community Development, 222-238.

${ }^{1}$ E. T. Bristol-Alagbariya (2010 [n11]), 24 and 328; E. T. Bristol-Alagbariya, Petroleum Development \& the Environment in Rivers State Nigeria: Fallouts of the UNEP Report on Ogoniland, Environmental Regulatory Standards \& Sustainable Development Laws \& Practices (LAP LAMBERT Academic Publishing 2018), 47; R. Sidaway, Resolving Environmental Disputes from Conflicts to Consensus (Earthscan 2013).

2 J. G. Frynas and S. Pegg (eds) Transnational Corporations and Human Rights (Palgrave Macmillan 2003); M. Watts (eds), Curse of the Black Gold: 50 Years of Oil in The Niger Delta (powerHouse [pH]Books 2010); O. Douglas and I. Okonta (n12).

${ }^{3}$ O. Douglas and I. Okonta (n12); O. Oluduro (n85), 160-166; R. Cui (n85); A. Manirabona and Y. V. Cárdenas (n85).

${ }^{4}$ K. Oyende, Oil Pollution Law and Governance in Nigeria (Stirling-Horden Publishers 2017); J. Akpokodje and S. Salau, 'Oil Pollution and Agricultural Productivity in the Niger Delta of Nigeria' [2015] 6 (4) Journal of Environmental Economics, 68-75; O. Awoyemi, The Impact of Oil Pollution on the Environment of the Oil Producing Communities of Nigeria: A Critical Analysis of the Statutory and Regulatory Provisions in Nigeria (Independent Law Publishing 2014); F. Allen, Implementation of Oil Related Environmental Policies in Nigeria: Government Inertia and Conflict in the Niger Delta (Cambridge Scholars Publishing 2012).

${ }^{5}$ United Nations Environment Programme (UNEP), (UNEP 2011[n12]); UNEP, Healthy Environment, Healthy People (UNEP 2016).

${ }^{6}$ A. Ogbuigwe (n85); A. Ogbuigwe, Legal Issues in the Niger Delta Resource Dilemma: A Collection of Essay (Anpez Centre for Environment and Development 2018); D. A. Omoweh (n12).

${ }^{7}$ S. Osha, Ken Saro-Wiwa's Shadow: Politics, Nationalism and the Ogoni Protest Movement (Adonis \& Abbey Publishers 2007); J. G. Frynas, Oil in Nigeria: Conflict and Litigation between Oil Companies and Village Communities (n12); J. G. Frynas, Oil in Nigeria: Community Rights and Corporate Dominance in Conflict (n12); A. Onuoha, From Conflict to Collaboration: Building Peace in Nigeria's Oil-Producing Communities (Adonis \& Abbey Publishers 2005).

${ }^{8}$ M. Watts, 'Petro-Insurgency or Criminal Syndicate? Conflict \& Violence in the Niger Delta' [2007] 43 (114) Review of African Political Economy, 637-660.

${ }^{9}$ K. Omeje, High Stakes and Stakeholders: Oil Conflict and Security in Nigeria (Routledge 2016); F. Allen (n91); J. S. Omotola, 'From the OMPADEC to the NDDC: An Assessment of State Responses to Environmental Insecurity in the Niger Delta, Nigeria' [2007] Africa Today, 73-89.

${ }^{10}$ I. Bannon and P. Collier (eds), Natural Resources and Violent Conflict: Options and Actions (The World Bank 2003); T. Tamuno, Oil Wars in the Niger Delta 1849 -2009 (Stirling-Horden Publishers 2011); F. Allen (n91); C. Obi and S. A. Rustad (eds), Oil and Insurgency in the Niger Delta: Managing the Complex Politics of Petroviolence (Zed Books 2011); V. Ojakorotu, Oil Exploitation and Conflict in the Niger-Delta Region of Nigeria (APSS Press 2009); V. Ojakorotu (ed), Fresh Dimensions on the Niger Delta Crisis of Nigeria (JAPSS Press 2009); N. S. Akpan and E. M. Akpabio, 'Oil and Militancy in Nigeria's Niger Delta: A "Development Catalyst" or "Development in Reverse"?' [2008] 10 (2) South South Journal of Culture and Development, 265285; S. I. Omofonmwan and L. O. Odia, 'Oil Exploitation and Conflict in the Niger-Delta Region of Nigeria' [2009] 26 (1) Journal of Human Ecology, 25-30; N. S. Akpan and E. M. Akpabio, 'Oil and Conflicts in the Niger Delta Region, Nigeria: Facing the Facts' [2009] 24 (1) Journal of Social Development in Africa, 9-35; A. Ogidiolu, 'Effects of Gas Flaring on Soil and Vegetation Characteristics in Oil Producing Region of Niger Delta, Nigeria' [2003] 1 (1), International Journal of Ecology and Environmental Dynamics, 47-53; Frynas, Oil in Nigeria: Conflict and Litigation between Oil Companies and Village Communities (n12); J. G. Frynas, Oil in Nigeria: Community Rights and Corporate Dominance in Conflict (n12). 
movement, ${ }^{1}$ which advocates that the region deserves maximum benefits from petroleum development operations in its oil-rich communities. Due to the fact that they are ethnic minorities, the people of the oil-rich Delta region are fundamentally being unfairly and inequitably treated ${ }^{2}$ by the Federal Government (FG) and the oil producing companies, led by the multinational oil and gas companies (MNOCs), operating in Nigeria such that there are prevalence of very high costs, negative consequences and paradoxes of petroleum energy resources development operations in the region. ${ }^{3}$ Hence, the Niger Delta region is poorer, more backward, politically and economically neglected, underdeveloped ${ }^{4}$ crises-ridden and highly an environmentally endangered region, perhaps, the most endangered Delta region in the world. ${ }^{5}$ The state of the endangered oil-rich Niger Delta region became worse because of the absence of government social responsibility (GSR) ${ }^{6}$ and lack of corporate social responsibility (CSR) measures, particularly social responsibility measures of MNOCs operating in the region. ${ }^{7}$

In particular, burning fossil fuels in the Nigerian oil-rich Delta region in the course of petroleum development operations, by MNOCs,${ }^{8}$ such as by gas flaring, ${ }^{9}$ as well as local (illegal) refining of crude oil, ${ }^{10}$ are

${ }^{1}$ O. V. C. Okene (ed), Readings in Law and Policy (Current Issues and Trends): (In Commemoration of the Golden Jubilee of Rivers State (1967-2017) (Faculty of Law, Rivers State University 2017) 129-144; E. T. Bristol-Alagbariya, 'Theories and the Legal Principle of Permanent Sovereignty over Natural Wealth and Resources in Relation to Petroleum Development in Nigeria' [2019] 4 (2) University of Port Harcourt Journal of Private Law, 208-209; E. T. Bristol-Alagbariya (2010 [n11]), 40-43; A. Ogbuigwe (n85); 15 and 17; A. Ogbuigwe (n93), 7.

${ }^{2}$ E. T. Bristol-Alagbariya (2019 [n98]), 198 and 208-209; K. S. A. Ebeku, Oil and the Niger Delta People in International Law: Resource Rights, Environmental and Equity Issues (Rüdiger Köppe Verlag Köln 2006); S. Azaike, Inequities in Nigerian Politics (Treasure Communications Resource 2003); Z. Adangor, Federalism and Natural Resource Governance in Nigeria: An Agenda for Constitutional Reform (Sibon Books 2015).

${ }^{3}$ J. K. Wangbu, The Niger Delta Paradox Impoverished in the Midst of Abundance (Safari Books 2018); S. C. Ugoh and W. I. Ukpere, Environmental Policy in Nigeria: Paradox of Niger Delta Sustainable Development [2012] 37 (3) Journal of Human Ecology, 151-158; O. Okoi, 'The Paradox of Nigeria's Oil Dependency' $<$ https://www.africaportal.org/features/paradox-nigerias-oil-dependency/> Accessed 27 April, 2020.

${ }^{4}$ E. V. Clark, 'The Politics of Oil in Nigeria: Transparency and Accountability for Sustainable Development in the Niger Delta' [2016] 6 (4) American International Journal of Contemporary Research, 76-82; M. T. Akobo et al (Southern Minorities Movement)/The Willink Commission, NIGERIA Report of the Commission Appointed to Enquire into The Fears of Minorities and The Means of Allaying Them (Southern Minorities Movement [SMM] [reprint] 1996), ii and 94; D. S. P. Alamieyeseigha (n85); E. T. Bristol-Alagbariya, Primordial Niger Delta, Petroleum Development in Nigeria and the Niger Delta Development Commission Act: A Food For Thought! [2020] 10 (3) Developing Country Studies, 118-119.

${ }^{5}$ D. M. J. Fubara (ed), 'The Endangered Environment of the Niger Delta: An NGO Memorandum of the Rivers Chiefs and Peoples' Conference', Port Harcourt, Nigeria, for the World Conference of Indigenous Peoples on Environment and Development and The United Nations Conference on Environment and Development, Rio de Janeiro, Brazil [1992], especially 1 and 16; E. T. Bristol-Alagbariya (2010 [n11]), 73 and 323; E. T. BristolAlagbariya (2018 [n88]), 32; E. T. Bristol-Alagbariya, 'Duties in Permanent Sovereignty over Natural Wealth and Resources and Petroleum Development in Nigeria: Towards Efficient Government Institutions and Greater Social Responsibility in the Country' [2019] 92 Journal of Law, Policy and Globalization, 89-90.

${ }^{6}$ E. T. Bristol-Alagbariya (2019 [n102]), 78-79, 82 and 89-91.

${ }^{7}$ B. Manby (n12); 146-169; O. Douglas and I. Okonta (n12); J. G. Frynas, Oil in Nigeria: Conflict and Litigation between Oil Companies and Village Communities (n12); J. G. Frynas, Oil in Nigeria: Community Rights and Corporate Dominance in Conflict (n12); E. T. Bristol-Alagbariya (2010 [n11]), 12-16, 28-34, 45, 196-227, 326-336; E. T. Bristol-Alagbariya, 'Ongoing Reform of the Nigerian Petroleum Industry: The Case of the Oil Producing Communities and Positive Transformation of Nigeria' [2016] 13 (1-2) Environmental and Planning Law Review, 1215-1245; B. Maiangwa and D. E. Agbiboa, 'Oil Multinational Corporations, Environmental Irresponsibility and Turbulent Peace in the Niger Delta' [2013] 48 (2) Africa Spectrum, 71-83; R. Sidaway (n88); A. Onuoha (n94).

${ }^{8}$ J. Rexler, 'Beyond the Oil Curse: Shell, State Power, and Environmental Regulation in the Niger Delta' [2010] 12 (1) Stanford Journal of International Relations, 26-31.

${ }^{9}$ S. Giwa, Emission Inventory for Gas Flaring in Nigeria: Baseline Black Carbon Emission Inventory for Gas Flaring in the Niger Delta Region of Nigeria (LAP LAMBERT Academic Publishing 2014); F. S. Eseduwo, Gas Flaring and Reinjection Policy-Making in Nigeria: Why Gas Reinjection Policies work in other Oil-producing Countries and Fail in Nigeria (LAP LAMBERT Academic Publishing 2014); E. Odigie, Associated Gas Injection Feasibility in the Niger Delta: A Case Study of the Southern Swamp Fields (Nigeria) (LAP LAMBERT Academic Publishing 2013); A. Ogidiolu (n97).

${ }^{10}$ M. Peel, A Swamp Full of Dollars: Pipelines and Paramilitaries at Nigeria's Oil Frontier (Lawrence Hill 
harmful to the environment, as same degrade, devastate and despoil the environment, ecosystems and ecosystem services in the region. Carbon is the main element in fossil fuels. ${ }^{1}$ For this reason, the millions of years that it takes fossil fuels to be formed are called the carboniferous period. When burnt, fossil fuels release carbon dioxide, a key greenhouse gas, into the atmosphere. ${ }^{2}$

Greenhouse gases trap heat from the sun in the Earth's atmosphere, causing temperatures to rise (global warming). Global warming describes the current rise in the average temperature of Earth's air and oceans. Often, global warming is described as the most recent example of climate change. Greenhouse gases include carbon dioxide $(\mathrm{CO} 2)$, methane $(\mathrm{CH} 4)$ and nitrous oxide $(\mathrm{N} 2 \mathrm{O})$. These gases are released during the combustion of fossil fuels to produce electricity. Carbon dioxide makes up the vast majority of greenhouse gas emissions from the sector of fossil fuels. Although water vapour is the most abundant greenhouse gas, it is relatively nonharmful as other greenhouse gases. Greenhouse gases in the atmosphere absorb infrared radiation (also called 'infrared light' or otherwise put, 'infrared rays' - kind of dangerous heat) from the sun and release same in all directions. Some of the heat so released and the heat from the sun penetrate the atmosphere. In the process, a measure of heat is reabsorbed by greenhouse gases to perpetuate the life cycle of these gases. The continuity of the life cycle of greenhouse gases means persistent presence of heat in the atmosphere. It is however natural and necessary to have some degree of greenhouse gases in the atmosphere, without which ecosystem would be impossible. In fact, the natural and necessary degree of greenhouse gases, which balances the degree of carbon in the atmosphere, is essential for life on Earth. Thus, the problem is abnormal or increased emission of greenhouse gases. Among others, the negative effects of increased emission of greenhouse gases include the following: global warming and climate change, deforestation and forest degradation in tropical areas, ocean acidification, rise of sea levels, increased melting of snow and ice, smog pollution, ozone layer depletion and difficulty of plants to absorb sufficient nutrients and the consequent distortion of their normal growth rate. ${ }^{3}$

The negative consequences of EIOs are more conspicuous in developing countries, where these operations take place in poor, rural and marginalised communities, such as those of the oil-rich Delta region of Nigeria. These negative consequences are even worse in resources-rich developing countries, like Nigeria, suffering from the resource curse. ${ }^{4}$

Books/Chicago Review Press 2009/I. B. Tauris \& Co 2011); C. Obi and S. A. Rustad (eds) (n97); The Nation newspaper, Nigeria), 'Unending illegal refining in Niger Delta' $<$ https://thenationonlineng.net/unending-illegalrefining-in-niger-delta/>; U. Akpan and P. Brisibe (Vanguard newspaper, Nigeria), 'Panic as oil theft, illegal refining increase in Niger Delta' $<\underline{\text { https://www.vanguardngr.com/2018/06/panic-oil-theft-illegal-refining- }}$ increase-niger-delta/>both Accessed 27 April, 2020.

${ }^{1}$ E. Roston, The Carbon Age: How Life's Core Element Has Become Civilization's Greatest Threat (Walker \& Company 2009); A. Epstein (n55); C. N. Daggett, The Birth of Energy: Fossil Fuels, Thermodynamics, and the Politics of Work (Duke University Press Books 2019).

${ }^{2}$ S. Pisupati (College of Earth and Mineral Sciences, The Pennsylvania State University), 'EGEE 102 Energy Conservation and Environmental Protection: Fossil Fuel Elements' <https://www.eeducation.psu.edu/egee102/node/1950>; C. Nunez (National Geographic Society), 'ENVIRONMENT: EXPLAINER: Carbon dioxide levels are at a record high. Here's what you need to know' $<$ https://www.nationalgeographic.com/environment/global-warming/greenhouse-gases/>; $\quad$ C. $\quad$ Batema (Sciencing), Elements in Fossil Fuels' $<$ https://sciencing.com/elements-fossil-fuels-7166.html $>$ all Accessed 27 April, 2020.

${ }^{3}$ E. T. Bristol-Alagbariya (2018 [n88]), 60; P. L. Ward, What Really Causes Global Warming?: Greenhouse Gases or Ozone Depletion? (Morgan James Publishing 2015); L. Parker, Climate Change: Design Approaches for a Greenhouse Gas Reduction Program (BiblioGov 2013); J. K. Casper, Greenhouse Gases: Worldwide Impacts (Facts on File 2010); R. C. Dalal and D. E. Allen, 'Greenhouse Gas Fluxes from Natural Ecosystems', [2008] 56 (5) Australian Journal of Botany, 369-407; M. Jaccard (n60); M. G. R. Cannel and M. D. Hooper (eds) (Institute of Terrestrial Ecosystem, Natural Environment Research Council [NERC]), The Greenhouse Effect and Terrestrial Ecosystems of the UK; ITE Research Publication No. 4 (Controller Her Majesty's Stationery Office [HMSO] 1990); United States Environmental Protection Agency (US EPA), 'Environmental Topics', captioned 'Climate Change Indicators' <https://www.epa.gov/climate-indicators $>$; US EPA, 'Greenhouse Gas Emissions: Overview of Greenhouse Gases' < https://www.epa.gov/ghgemissions/overviewgreenhouse-gases >; National Geographic Society, Effect'

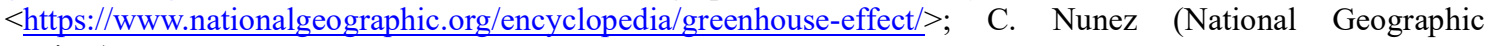
Society), 'CAUSES AND NFFCTS OF CLIMATE $<$ https://www.nationalgeographic.com/environment/global-warming/global-warming-overview/> all Accessed 27 April, 2020.

${ }^{4}$ N. Mirovitskaya and W. Asher (eds), Guide to Sustainable Development and Environmental Policy (Duke University Press 2001) 9 and 17; P. J. Stevens, 'The Resource Curse Revisited Appendix: A Literature Review' 
Generally, over and again, studies around the globe on Mining, Minerals and Sustainable Development (MMSD) project, the World Bank Group (WBG) Extractive Industries Review (EIR) and other follow-up studies, processes and practical evidences are consistently proving that EIOs, such as oil and gas and other mineral resources industrial development operations, essentially inhibit SD. ${ }^{1}$ In the event of EIOs in resourcesrich rural communities like those of the Niger Delta region, these communities are being unfairly and inequitably treated because they bear most of the costs (burdens) and adverse consequences of the operations and yet remain poor and marginalised. ${ }^{2}$ In the oil-rich ethnic minority Niger Delta region, this situation has been so, to recall for the sake of emphasis, for over six decades of petroleum development operations. By and large, petroleum resources development operations fundamentally inhibit SD in the Niger Delta region.

However, researches and practical evidences are increasingly demonstrating that EIOs operations are advantageous when these operations are implemented well. That means, when extractive industrial projects are executed in a way that preserve the rights of members of the public who are adversely affected by these projects and when the benefits derived from these projects are well-utilised towards overall public good. In essence, if EIOs, such as petroleum resources development projects are properly governed in conformity with international benchmarked standards and practices, these can contribute to poverty reduction and SD. On this note, good environmental governance (GEG) measures, ${ }^{3}$ such as efficient EA and environmental management systems, good oil-field standards and practices, ${ }^{4}$ good corporate governance systems, such as good business ethics, as well as other SD-oriented measures and practices are capable of making EIOs contribute to SD. ${ }^{5}$.

\subsubsection{Problems Related to Petroleum Resources Development Operations in Nigeria}

We have already stated that the problems arising from petroleum resources development operations in the oil-rich Niger Delta and other oil producing areas of Nigeria are aspects of the problems associated with these resources development operations in the broader and wider Nigerian nation. Some of these problems and challenges of petroleum resources development are sub-optimal performance of the Nigerian national oil company (the Nigerian National Petroleum Corporation [NNPC]), ${ }^{6}$ apart from lack of technological and managerial prowess, Nigeria's status of rentier economy (rentier state), resource curse and underdeveloped economy. ${ }^{7}$ There are also the problems of energy security (including insecurity of supply to Nigeria's consumer

[2015] The Royal Institute of International Affairs, 1-42; P. J. Stevens, 'The Resource Curse and How to Avoid It' [2006] 31 (1) The Journal of Energy and Development, 1-20; F. van der Ploeg, 'Natural Resources: Curse Or Blessing?' [2011] 49 (2) Journal of Economic Literature, 366-420; E. T. Bristol-Alagbariya (2018 [n7]), 43; E. T. Bristol-Alagbariya (2010 [n11]), 49, 75, 147 and 318; E. T. Bristol-Alagbariya, 'The Concept, Principle, Law and Developmental Practice of Environmental Democracy towards Sustainable Development in Resources-rich Communities of Developing Countries: Focus on Nigeria's Oil Producing Delta Region' [2020] 94 Journal of Law, Policy and Globalization, 53, 55, 61-62, 66 and 69; J. Rexler (n105); C. Obi, 'Oil as the 'Curse' of Conflict in Africa: Peering through the Smoke and Mirrors' [2010] 37 (126) Review of African Political Economy, 483495; Principle 3, UN Stockholm Declaration on the Human Environment, 1972.

${ }^{1}$ International Institute for Environment and Development (IIED) and World Business Council for Sustainable Development (WBCSD) (n11); World Bank Group, 'Striking a Better Balance - The World Bank Group and Extractive Industries: The Final Report of the Extractive Industries Review, World Bank Group Management Response' (n11); L. Barrera-Hernandez et al (eds) (n82); E. T. Bristol-Alagbariya (2010 [n11]), 83-101, especially 100 .

${ }^{2}$ L. Barrera-Hernandez et al (eds) (n82); especially preview, v and 1.

${ }^{3}$ A. Sapat (ed), Routledge Handbook of Environmental Governance (Routledge 2017).

${ }^{4}$ M. J. Hatami, Oilfield Survival Guide, Volume One: For All Oilfield Situations (Oilfield Books 2016); Law Insider, 'Definition of good oil-field practice' $<$ https://www.lawinsider.com/dictionary/good-oilfield-practice $>$; Drilling Lexicon, 'Good Oilfield Practice' <http://www.iadclexicon.org/good-oilfield-practice/>; both Accessed 27 April, 2020.

${ }^{5}$ E. T. Bristol-Alagbariya, 'The UN Global Compact as a Soft Law Business Regulatory Mechanism Advancing Corporate Responsibility towards Business Sustainability and Sustainable Development Worldwide' [2020] 94 Journal of Law, Policy and Globalization, 27-39.

${ }^{6}$ A. Sayne et al, Inside NNPC Oil Sales: A Case for Reform in Nigeria (Natural Resource Governance Institute 2015); D. L. Losman, 'The Rentier State and National Oil Companies: An Economic And Political Perspective' [2010] 64 (3) Middle East Journal, 427-445; c/f homepage of the NNPC, <https://www.nnpcgroup.com/Pages/Home.aspx $>$; Equinor, 'About us' $<$ https://www.equinor.com/en/about-us.html $>$; Petrobras, 'About us' $<$ http://www.petrobras.com.br/en/about-us/>; Petronas, 'About us' <https://www.petronas.com/about-us $>$; all Accessed 27 April, 2020.

${ }^{7}$ S. Adelaja, The Nigeria Economy: The Way Forward: Taking Nigeria from Economic Recession into Global Economic Dominance (Golden Pen 2017); T. S. Akinyetun, Developing in Underdevelopment in Nigeria: The 
nations and their numerous consumer-public) and energy efficiency, generating the resultant problems of energy poverty, ${ }^{1}$ particularly poverty of petroleum energy resources (petroleum energy poverty). Yet other problems are generic poverty ${ }^{2}$ plaguing Nigerian citizens in the midst of plenty and general insecurity of lives and property in the country. Above all, is the perennial problem of corruption, ${ }^{3}$ particularly corrupt political leadership and its all-embracing problem of bad governance. ${ }^{4}$ Considering that there is so much information in the public domain on these problems and challenges militating against sustainable petroleum resources development operations, this study will not discuss these problems and challenges further.

However, suffice it to mention that the problem of lack of technological and managerial prowess of Nigeria essentially contributes to the country's status in the development and operation of its petroleum industry and in turn its continued existence as a rentier state, with its petroleum-based industrial economy continuously existing as a rentier economy. ${ }^{5}$ The enormous wealth accruing from petroleum (oil and gas) development operations has been the mainstay ${ }^{6}$ of Nigeria's political economy for several decades. However, due to Nigeria's selfish and self-serving political leadership, ${ }^{7}$ this enormous wealth is being mismanaged, misappropriated and primitively accumulated by the political leaders of the country. ${ }^{8}$ Accordingly, it is due to the problem of corrupt political leadership and its associated perennial problem of bad governance, that there is abysmal poverty, destitution, as well as insecurity of lives and property in the country. ${ }^{9}$ Moreover, it is crystal clear that fighting institutionalised corruption, entrenched in bad governance, in Nigeria is not only risky but also dangerous. ${ }^{10}$ Bad governance, which is increasingly occasioning doubt and mistrust between the institution of government and the citizenry (the governed) ${ }^{11}$ and driving Nigeria to a failing or a failed state, is the principal reason why petroleum and other energy and major natural resource development operations in the country are inefficient and/or ineffective, as these operations fall short of international benchmarked standards and practices of energy resources EIOs, which standards and practices are designed to make these operations contribute to SD. ${ }^{12}$

Hand of Corruption (CreateSpace Independent Publishing Platform 2016); S. S. Mahmud, State, Class and Underdevelopment in Nigeria and Early Meiji Japan (Palgrave Macmillan 1996).

${ }^{1}$ A. Adenikinju et al (eds) (n4), 538-561; Y. Omorogbe and A. O. Ordor (eds) (n14), 5, 12-13, 131, 162, 209, 377, 380-381 and 384.

${ }^{2}$ M. Yusuf, The Relationship between Good Governance and Poverty in Nigeria (LAP LAMBERT Academic Publishing 2015); B. Onimode, Imperialism and Underdevelopment in Nigeria: The Dialectics of Mass Poverty (Zed Press 1982).

${ }^{3}$ D. J. Smith, A Culture of Corruption: Everyday Deception and Popular Discontent in Nigeria (Princeton University Press (2008); N. Okonjo-Iweala, Fighting Corruption Is Dangerous: The Story Behind the Headlines (The Massachusetts Institute of Technology [MIT] Press 2018); E. O. Iwobi, Corruption in the Nigerian Public Service, Nipping It in the Bud (Xlibris 2014).

${ }^{4}$ C. Achebe, The Trouble with Nigeria (Fourth Dimension 1983).

${ }^{5} \mathrm{~K}$. Omeje (ed), Extractive Economies and Conflicts in the Global South: Multi-Regional Perspectives on Rentier Politics (Ashgate Publishing 2008); K. Omeje, 'The Rentier State: Oil-related Legislation and Conflict in the Niger Delta, Nigeria [2007] 6 (2) Conflict, Security \& Development, 211-230; D. S. Olawuyi, Extractives Industry Law in Africa (Springer Nature Switzerland AG 2018); P. D. Cameron and M. C. Michael, Oil, Gas, and Mining: A Sourcebook for Understanding the Extractive Industries (World Bank Group 2017); A. K. Usman, Nigerian Oil and Gas Industry Laws (Malthouse Press 2017).

${ }^{6}$ O. E. M. Nwoba and E. O. Abah, 'Impact of Crude Oil Revenue (COR) On Economic Growth in Nigeria (1960-2010)’ [2017] 22 (7) IOSR Journal of Humanities and Social Science (IOSR-JHSS), 85-99.

${ }^{7}$ A. Osita-Njoku, 'The Political Economy of Development in Nigeria: From the Colonial to Post Colonial Eras' [2016] 21 (9), IOSR Journal of Humanities and Social Science (IOSR-JHSS), 9-15, especially 9 and 13-14.

${ }^{8}$ A. Gillies, Crude Intentions: How Oil Corruption Contaminates the World (Oxford University Press 2020).

${ }^{9}$ C/f L. Helms (ed), Poor Leadership and Bad Governance: Reassessing Presidents and Prime Ministers in North America, Europe and Japan (New Horizons in Leadership Studies Studies) (Edward Elgar Publishing 2012); T. Jackson (2009 [n3]); T. Jackson (2011 [n3]); J. O. Ojeme, 'A Critical Appraisal of African Largest Economy Ravaged in Poverty \& Destitution (A Case Study of Nigeria in the Light of the Recent Rebasing Nigerian GDP)'[2017] 3 (2) International Institute of Academic Research and Development (IIARD), 29-52; BBC News, 'Nigeria: Oil-gas sector mismanagement costs billions' $<$ https://www.bbc.com/news/world-africa20081268> Accessed 27 April, 2020.

${ }^{10}$ N. Okonjo-Iweala, Fighting Corruption Is Dangerous: The Story Behind the Headlines (The Massachusetts Institute of Technology [MIT] Press 2018); R. Rose and C. Peiffer, Bad Governance and Corruption: Political Corruption \& Governance (Palgrave Macmillan 2019).

11 J. S. Nye et al, Why People Don't Trust Government (Harvard University Press 1997).

12 IIED and WBCSD (n11); World Bank Group, 'Striking a Better Balance - The World Bank Group and Extractive Industries: The Final Report of the Extractive Industries Review, World Bank Group Management 
Consequently, while examining the core problem of Nigeria, the country's erudite scholar and prolific writer, who is described as 'a moral voice in the anthills of decadence', Chinua Achebe, proclaimed that 'the trouble with Nigeria is simply and squarely a failure of leadership. ${ }^{1}$ So far, Nigerian political leaders are yet to challenge this proclamation of Achebe's by delivering GG in the overall interest of Nigeria, its component ethnic nationalities, citizens and residents.

\subsubsection{Ethics Associated with Energy Resources Development Operations, including Petroleum Development Operations in Nigeria}

The ethics, ethical issues or morally good behaviours associated with energy resources operations in general and energy resources development operations in particular are designed to ensure sustainability of these operations, such that they would contribute to SD.

SD may be described and defined in certain relative ways. The WCED gives a classic definition of SD, which we hereby wish to adopt. The Commission defines SD as the development which meets the needs of the present generation without compromising the ability of future generations to meet their own needs. ${ }^{2} \mathrm{We}$ wish to reinforce the classic definition of SD with the proposal and proclamation of the Earth Charter Initiative (ECI), which espouses the values and principles for building a more just, sustainable and peaceful world, highlights that SD expands our vision towards ethical or greater ethical principles and practices. ${ }^{3}$ This Charter is an international declaration of fundamental values and principles, having its constituent global movement of organisations and individuals that embrace the declaration for building vision, attitude, knowledge, wisdom, skills and values needed to achieve a more just, sustainable and peaceful global society. ${ }^{4}$

Given that it is designed to regulate the intertwined and interwoven relationship of the environment to development, SD involves promoting and/or ensuring sustainable human progress, prosperity and survival in the course of development, without endangering the environment and bankrupting the resources of future generations. Therefore, the main recommendation of the WCED, which is considered as the solution to the compelling demand for environmental protection in the course of economic development, is a new approach, namely SD. To achieve SD, sovereign states (countries), government, business, individuals, civil society organisations and all other sectors of society are required to put the environment first, so that development may last. ${ }^{5}$ On this note, the WCED, which urges the entire countries, groups and peoples of the global community to seriously and conscientiously promote the intertwined and interwoven relationship of the environment to development, recommends that in the final analysis SD must rest on political will. ${ }^{6}$ By virtue of this recommendation, the Commission puts onus of primarily achieving SD on sovereign states (countries and nations) of the world. The publication of the WCED, entitled Our Common Future (the future of the entire global community on Planet Earth), which was published in 1987, may be considered as a general notice to the entire community of countries and peoples of the globe that time is rife for them to vigorously work towards promoting and actualising marriage of the economy and efficient environmental protection, through conservation, preservation of ecology, ecosystems and ecosystem services, as a means to promote, support and

Response' (n11); E. T. Bristol-Alagbariya, 'Duties in Permanent Sovereignty over Natural Wealth and Resources and Petroleum Development in Nigeria: Need to Domesticate Benchmarked International Standards and Practices in the Country' [2019], 92 Journal of Law, Policy and Globalization, 95-107; E. T. Bristol-Alagbariya, 'Duties Inherent in Permanent Sovereignty over Natural Wealth and Resources: A Case for Domestication of Benchmarked Regulatory Standards and Practices Governing Petroleum Development in Nigeria' (2019) 11 (1) Journal of Property Law and Contemporary Issues, 134-152; R. Hannesson, Investing for Sustainability: The Management of Mineral Wealth (Kluwer 2001).

${ }^{1}$ C. Achebe, The Trouble with Nigeria (Fourth Dimension 1983), 1-3; Ofọdunka, 'The Guardian Man of The Year: Chinua Achebe' <http://chikaokeke-agulu.blogspot.com/2012/01/guardian-man-of-year-chinuaachebe.html $>$; S. Baldauf..., 'Chinua Achebe on corruption and hope in Nigeria' $<$ https://www.csmonitor.com/World/Africa/2013/0322/Chinua-Achebe-on-corruption-and-hope-in-Nigeria $>$

Accessed 27 April, 2020; E. T. Bristol-Alagbariya (2013 [n21]), xxxix, 57-58 and 286.

${ }^{2}$ WCED (n2), 8, 40 and 43.

${ }^{3}$ Homepage of the Earth Charter Initiative <http://earthcharter.org/>; The Earth Charter, 'Earth Charter Education' $<$ https://earthcharter.org $>$ Accessed 7 February, 2020.

${ }^{4}$ Ibid; P. B. Corcoran (ed), The Earth Charter in Action: Toward a Sustainable (KIT Publishers 2006); UN Association of Australia (UNAA), The Earth Charter (UNAA 2017).

${ }^{5}$ WCED (n2), ix-66, particularly back cover review and 1-2; P. Bartelmus (n24); D. A. Munro, Caring for the Earth: A Strategy for Sustainable Living (Union Internationale pour la Conservation de la Nature et de ses Ressources, Switzerland 1994); IUCN et al, Caring for the Earth: 5 (Sustainable Development Set) (Earthscan 2009); T. Jackson (2009 [n3]); T. Jackson (2011 [n3]).

${ }^{6}$ WCED (n2), 9. 
sustain the carrying capacity of the Earth, towards the wellbeing and survival of the present and future humanity. ${ }^{1}$

The ethics associated with energy resources development operations, including petroleum development operations in Nigeria arise from the costs, negative consequences and paradoxes of petroleum energy resources development operations in the oil-rich ethnic minority Delta region and other oil producing areas of Nigeria. We have already taken an overview of the decades of costs, negative consequences and paradoxes of petroleum energy resources development operations in the oil-rich ethnic minority Delta region of Nigeria, including other oil producing areas of the country. By and large, the ethics of energy resources development operations are thus related to the costs, paradoxes and negative consequences of these operations on SD.

Considering that these ethics, ethical issues and aspects of access to and use of energy resources development operations are many, they may, from the background, profession-leaning and perspectives of different scholars, be phrased differently and considered as holistic, inter-related or even open-ended, as their scope covers the life-cycle of energy and major natural resources extractive industrial operations (EIOs). Nevertheless, some of these ethics may be outlined as they are listed here-under: ${ }^{2}$

(i) Ethics associated with energy and major natural resources EIOs;

(ii) Ethics associated with Permanent Sovereignty over Natural Wealth and Resources (PSNWR), regarding energy and major natural resources development;

(iii) Ethical nature of the growing recognition of the stakeholder approach to business, with regard to energy and major natural resources development operations;

(iv) Ethics in relation to Government Social Responsibility (GSR), Corporate Social Responsibility (CSR) and Social Responsibility of affected civil society groups in energy and major natural resources development operations;

(v) Ethics associated with technology and innovation, particularly new and cleaner technologies;

(vii) Ethics associated with good oilfield standards and practices in petroleum and other energy and major natural resources development operations;

(viii) Ethics associated with Health, Safety and Environment (HSE) in petroleum and other energy and major natural resources development operations;

(ix) Ethics associated with greenhouse gas emission in the course of petroleum and other energy and major natural resources development operations;

(x)Ethics in relation to the UN Global Compact, in the course of petroleum and other energy and major natural resources development operations;

(xi) Ethics associated with geopolitical risks in the course of petroleum energy and other energy and mineral resources development operations;

(xii) Ethics associated with environmental assessment (EA) in the process of petroleum and other energy and major natural resources development operations;

(xiii) Ethics in relation to policy failures in developing countries regarding petroleum and other energy and major natural resources development operations;

(xiv) Ethics associated with decommissioning and abandonment of petroleum and other energy and major natural resources development operations;

(xv) Ethics associated with energy, petroleum and other major natural resources development operations towards peace, security and GG;

(xvi) Ethics associated with conservation, in the process of petroleum and other energy and major natural resources development operations;

(xvii) Ethic associated with sustainable development (a vast, versatile, multidimensional and all-encompassing ethical feature); and

(xviii) Ethics associated with affordable, reliable, sustainable and efficient modern energy services towards overall public good.

\subsubsection{Ethics Associated with Extractive Industrial Operations and Pertinent Remarks on Ethics}

So far, we have given an outline of the ethics associated with energy resources development operations, including petroleum development operations in Nigeria. We are proceeding to briefly discuss ethics associated with EIOs, as an example, and to make certain pertinent remarks.

One crucial ethical conduct, which is associated with energy and major natural resources, is regarding EIOs, listed as item (i) of our preceding sub-heading. As indicated earlier-on, EIOs have tremendous negative effects on the environment, occasion poverty and fundamentally inhibit SD. However, landmark studies,

\footnotetext{
${ }^{1}$ Ibid, ix-66.

${ }^{2}$ E. T. Bristol-Alagbariya, lecture slides, 'Energy, Petroleum, Business Law, Policy and Regulations and Ethics', Course Code: PEEM 811/12, (n14).
} 
corroborated by real-life evidences indicate that EIOs are advantageous when these operations are implemented well; that means, in a way that preserves the rights of people who are directly affected by extractive industrial projects, and when the benefits derived from these projects are well-utilised for overall public good. Thus, EIOs can contribute to environmental protection, poverty reduction and shared prosperity, and thereby promote SD. The ethics-in-action or morally good practice required in this context is for the owners and managers of EIOs to comply with international benchmarked standards and practices governing these operations, so as to ensure that they contribute to poverty reduction and SD. In this regard, GEG measures, such as efficient EA, environmental management systems, good oil-field standards and practices, good corporate governance systems, such as good business ethics, as well as other SD-oriented measures and practices, should be observed, to make EIOs contribute to poverty reduction and SD in resources-rich developing countries like Nigeria.

May we therefore remark by reiterating that various forms of ethics and ethical conducts associated with energy resources operations are aimed at sensitising and spurring those engaged in these operations to make the operations contribute to SD. These operations are in effect required to be embarked upon in ways that foster and enhance the achievement of Goal 7 of the UN Sustainable Development Goals (UNSDGs), captioned affordable and clean energy, which Goal is designed to ensure access to affordable, reliable, sustainable and efficient modern energy for all, by the year $2030 .^{1}$

\section{Ethics towards Sustainable Development of Energy Resources Development Operations and the Role of Law}

So far, we have given an outline of the ethics (ethical issues and ethical behaviours) associated with energy and major natural resources development operations and particularly discussed the ethics associated with EIOs. These ethical behaviours are designed to promote effective energy resources services, towards sustainable and efficient delivery of energy services to all societies and individuals around the globe.

Over and again, it has been mentioned that various manner of ethics and ethical conducts associated with energy resources operations, especially these resources development operations, are aimed at sensitising and spurning those engaged in these operations to make the operations contribute to SD. To do so, these operations are required to be embarked upon in ways that would achieve Goal 7 of the UNSDGs, captioned 'affordable and clean energy', which is designed to ensure access to affordable, reliable, sustainable and efficient modern energy for all, otherwise described as 'sustainable energy for all' (SEforALL). SEforALL is an international multistakeholder organisation promoting the need for energy efficiency and to increase the use of renewable energy resources, towards overall public good. ${ }^{2}$ However, to achieve the goals of SEforALL requires a radical rethink of the way the humankind in countries around the world produce, distribute and consume energy. ${ }^{3}$

The role of law in the context of this study is that it regulates energy resource activities. Law regulates energy and major natural resources development operations, such as petroleum resources development operations. For instance, law serves as the key instrument required for operations of energy and major natural resources regulatory institutions, as well as the operations of energy and major natural resources service providers. ${ }^{4}$ In effect, law governs various conducts of humans and society at large, so as to engender improved access to energy resources, towards affordable and clean energy for the survival and sustenance of all individuals..$^{5} \mathrm{Law}$ is an inevitable apparatus of social engineering, positive change and dynamic progress that governs conducts in countries around the globe, so as to enable them provide access to affordable, reliable, sustainable and efficient modern energy for all. Law is a veritable instrument of sustainable energy for all (SEforALL). ${ }^{6}$

Therefore, laws and legal instruments, especially those having moral features, serve the strategic role of governing energy resources operations to stimulate access to affordable, reliable and sustainable modern energy services for all individuals, including poor people residing in rural areas of developing countries, ${ }^{7}$ by

1 United Nations Development Programme (UNDP), 'Sustainable Development Goals' $<$ https://www.undp.org/content/undp/en/home/sustainable-development-goals.html > Accessed 27 April, 2020.

2 Homepage of SEforALL (n14).

${ }^{3}$ SEforALL, 'About us'< $<$ https://www.seforall.org/about-us $>$ Accessed 7 February, 2020.

${ }^{4}$ J. Rasband et al, Natural Resources Law and Policy (Foundation Press 2016); J. L. MacDonnell and S. F. Bates (eds), Natural Resources Policy and Law: Trends and Directions (Island Press 1993); Alam S., Bhuiyan J. H. and Razzaque J. (eds), International Natural Resources Law, Investment and Sustainability (Routledge 2018).

${ }^{5}$ A. Adenikinju et al (eds) (n4); Y. Omorogbe and A. O. Ordor (eds) (n14).

${ }^{6} \mathrm{Ibid}$; homepage of Sustainable Energy for All (SEforALL) (n14).

${ }^{7}$ M. H. Kramer (n39); Y. Omorogbe and A. O. Ordor (eds) (n14), 5, 12-13, 131, 162, 209, 377, 380-381 and 384; A. Adenikinju et al (eds) (n4), 538-561. 
2030. This is the target year agreed upon and proclaimed by the UN, regarding delivery of sustainable and efficient modern energy services to all societies and individuals around the globe. ${ }^{1}$

Regardless of the foregoing, ironically, law is still an unresolved mechanism of social engineering, positive change and dynamic progress in developing countries like Nigeria, which are plagued by the disease called 'energy poverty'. 2

\section{Conclusion}

In the context of the framework of this study, ethics may be considered as a wide and exploratory subject-matter of discourse, which appears like an elephant that may be described from many standpoints. Nevertheless, the study outlines certain ethics (also referred to as ethical issues, ethical behaviours (ethics-inaction: morally good practices) associated with energy and major natural resources development operations exemplified by petroleum development operations in Nigeria. The study also analyses the relationship between law and ethics. It discusses ethics as morals, namely morally good behaviours and practices, in relation to energy resources development operations in an open-ended manner.

The study also examines the relationship between law and morality and hence ethics, by exploring the domain of jurisprudence. It does so by examining the theory of natural law (and its school of thought), as opposed to the positive law theory (and its school of thought). It deliberates on the theory of natural law, which underscores the divine origin of law and leadership as well as the moral content law, so as to establish as well as demonstrate the effectual and dynamic relationship between law and morality. The theory of natural law school of thought argues that moral principles, rules and standards should or ought to be embedded in laws governing human societies, such as sovereign states. The theory of natural law underpins the moral foundation of laws, particularly the moral footprint of good laws. Conversely, the positive law theory presupposes that law is simply the rule, directive or command of a sovereign or sovereign state, the breach of which attracts sanction. As such, legal positivism argues that there is no need to use reason, morality, justice or fair-play to determine the nature and validity of law.

The moral content or feature of law espoused in the theory of natural law serves as a foundational outlay, background or platform for examining ethics relating to energy resources development operations in particular and the entire life-cycle of these resources activities, which are designed to promote effective energy resource operations, towards sustainable and efficient delivery of energy services to all societies and individuals around the globe.

Energy resources may be viewed as different categories of fuels used by humans for heating, generation of electrical energy and other forms of energy conversion processes. These resources are thus the sources from which energy is derived, produced and supplied for the use of human beings and overall benefit of society. The significance of energy resources to humans and society at large cannot be overemphasised, as these resources help to nourish and sustain life. Energy resources are necessary for the day-to-day sustenance and survival of humans and society at large. They are crucial and inevitable to the development, advancement and overall prosperity of the human race and society as a whole. Energy resources enhance the functionality, viability and vitality of other sectors to the economy of a country. The ability of humans to harness energy resources is arguably the most important step in the history of human civilisation.

The sources of global energy supply (energy resources) may be considered in two broad categories, namely non-renewable and renewable resources. Petroleum, a focal point of this study, is an example of fossil fuels, which constitutes most of the world's non-renewable energy resources.

From the period of the industrial revolution in Great Britain in the $18^{\text {th }}$ Century, to the $2^{\text {nd }}$ half of the $20^{\text {th }}$ Century, fossil fuels were the dominant forms of the world's energy resources. Great Britain led the world into industrialisation in the $18^{\text {th }}$ Century, when machines were powered by coal, following which electricity produced from burning coal, began to take over from manual labour. From the trend of consumption of energy resources and these resources-related services, some consider that petroleum resources, which are non-renewable fossil fuels' category of energy resources, would continue to be the major sources of the world's energy resources in the ongoing $21^{\text {st }}$ Century.

Using petroleum development operations in Nigeria as examples of energy resources development operations, the study examines the role of law as an instrument of social engineering, positive change and dynamic progress in society, to engender access to energy services for all societies and individuals around the globe, by 2030 (the target year proclaimed by the UN) regarding delivery of sustainable and efficient modern energy services to all. With the aid of socio-legal methodology, the study explores the nexus between energy poverty and bad governance prevailing in developing countries like Nigeria. It examines the connection between

${ }^{1}$ Goal 7 of the UNSDGs, captioned 'affordable and clean energy'.

${ }^{2}$ Y. Omorogbe and A. O. Ordor (eds) (n14), 5, 12-13, 131, 162, 209, 377, 380-381 and 384; A. Adenikinju et al (eds) (n4), 538-561. 
energy poverty and the multifaceted, multi-dimensional, versatile and all-encompassing negative consequences of bad governance on citizens, humanity at large and entire fabric of developing countries suffering from bad governance, like Nigeria. The study also examines the link between natural law (associated with morality), and good laws. Consequently, given the qualitative nature of good laws and their connection with morality; that means, how good laws have moral foundations, the study makes a case for the promotion of natural law (and its school of thought), as opposed to the positive law theory (and its school of thought). Clearly, natural law underpins the moral foundation of laws, particularly the moral footprint of good laws. Thus, based on the effectual and dynamic relationship between law and morality, the study promotes and justifies the existence and good potentials of natural law. In this way, the study underscores and highlights the significance of natural law as the bedrock of virtue and GG and thus a veritable, strategic and inevitable tool in the march of countries and peoples around the world as well as the entire global community, pioneered and ably being spearheaded by the UN, towards SD.

Petroleum resources are energy and major natural resources. These resources development operations are extractive industrial operations (EIOs), which have colossal negative effects on the environment and inhibit SD. The horrifying adverse consequences of petroleum resources development operations affect the oil-rich ethnic minority Delta region and other oil producing areas of Nigeria, as well as the entire Nigerian nation. The problems, costs (burdens), adverse consequences, challenges and paradoxes of petroleum resources development operations in the oil-rich ethnic minority Niger Delta region started after the commencement of these resources development operations in the oil producing communities of the region in the second half of the 1950s. The six States of the Delta region (Southern ethnic minorities: South-South geopolitical region of Nigeria), namely Rivers, Delta, Bayelsa, Akwa-Ibom, Edo and Cross-River States, are oil producing States of the country. These States, particularly Rivers, Delta, Bayelsa and Akwa-Ibom States are Nigeria's major oil-rich States.

There have therefore been well over six decades of costs (burdens), negative effects, challenges and paradoxes of petroleum resources EIOs in the oil-rich Delta region of Nigeria, including other oil producing areas of the country, such as Abia, Imo and Ondo States, in which areas the resources development operations commenced a few decades after the 1950s.

Various adverse effects of petroleum development operations in the Delta region and other oilproducing areas of Nigeria may be classified into environmental, socio-economic and political consequences. These adverse effects include paradox of poverty and misery in the midst of plenty, lack of genuine engagement of the citizens and citizen-groups in the course of the resources development operations in their communal homelands, ineffective development project-level environmental assessment, namely EIA, lack of life-cycle assessment of petroleum development projects and absence of institutionalised strategic environmental assessment (SEA) in Nigeria as well as lack of just and equitable impact-benefits and impact-benefits agreements (IBAs). There is generally lack of IBAs or other forms of Good Neighbour Agreements between oil companies and oil producing communities; rather, there is a regime of various forms of MoU between oil companies and oil producing communities, which are causing misunderstanding, confusion and crises in the communities. There are also other adverse effects of these development operations as negative health impacts, human rights abuses and violations, oil pollution, degradation, devastation and despoliation of the environment, ecology and ecosystems, as well as deterioration of ecosystem services in the oil-rich Delta region and other oil producing areas of Nigeria, thereby undermining the general wellbeing of the oil-rich communities, citizens and future generations of the communities. Yet other adverse consequences are community crises, which include violent conflicts aggravated by youth restiveness and insurgency, as well as insecurity of lives and property arising from the crises in the oil-rich communities of the ethnic minority oil-rich Delta region. These effects associated with unsustainable petroleum resources development operations in the Niger Delta region made the region to become endangered and crises-ridden and justified the region's historic 'resource control' movement, which advocates that the region deserves to have maximum benefits from petroleum development operations in its oil-rich communities. Due to the fact that they are ethnic minorities, the people of the oil-rich Delta region are fundamentally being unfairly and inequitably treated by the FG and the oil producing companies, led by the MNOCs, operating in Nigeria such that there are prevalence of very high costs, negative consequences and paradoxes of petroleum energy resources development operations in the region. Hence, the Niger Delta region is deplorably poorer, more backward, politically and economically neglected and underdeveloped as well as crisesridden and an environmentally endangered region, perhaps, the most endangered Delta region in the world, which is greatly being threatened by greenhouse gas emissions occasioning climate change and global warming in the region. The state of the endangered oil-rich Niger Delta region became worse because of the absence of government social responsibility (GSR) and lack of corporate social responsibility (CSR) measures, particularly social responsibility measures of MNOCs operating in the region.

The problems and challenges arising from petroleum resources development operations in the broader and wider Nigerian nation include the sub-optimal performance of the Nigerian national oil company (the Nigerian National Petroleum Corporation [NNPC]), lack of technological and managerial prowess, Nigeria's 
status of rentier economy (rentier state), resource curse and underdeveloped economy. Others are the problems of energy security (including insecurity of supply to Nigeria's consumer nations and their numerous consumerpublic) and energy efficiency, generating the resultant problems of energy poverty, particularly poverty of petroleum energy resources (petroleum energy poverty). Yet other problems are generic poverty plaguing Nigerian citizens in the midst of plenty and general insecurity of lives and property in the country. Above all, is the fundamental problem of corruption, particularly corrupt political leadership and its associated hydra-headed problem of bad governance. The study thus adopts the finding of Nigeria's erudite scholar and prolific writer, Chinua Achebe, that the failure of political leadership (bad governance) is the main problem of Nigeria.

Besides, in order to examine the role of law, the study defines law by stating that it is a system of binding modes of conduct, which are formulated to govern behavioural patterns, namely those of individuals, groups and entities in society. The study thus indicates that the role of law is to showcase the significance and essence of law in terms of regulating energy resource activities, so as to promote and actualise access to sustainable and efficient modern energy to all societies and individuals around the globe.

Certainly, law is a mechanism of social engineering, positive change and dynamic progress in society, which serves the strategic role of governing energy resources operations to stimulate realisation of the dream of the entire global community to ensure effective energy resource operations, towards providing efficient and sustainable delivery of energy services to all societies and individuals, including poor people residing in rural areas of developing countries, by 2030. This is the target year agreed upon and proclaimed by the UN, regarding delivery of sustainable and efficient modern energy services to all around the globe.

Also, the study gives account of a fundamental ethical conduct associated with energy and major natural resources development operational activities, which stipulates how petroleum and other EIOs, which have negative effects on the environment and inhibit SD, should be managed in a way to contribute to poverty reduction and SD. To do so, EIOs are required to be managed in a way that complies with international benchmarked standards and practices governing these operations. On this note, good environmental governance measures, such as efficient EA and environmental management systems, good oil-field standards and practices, good mining and overall good corporate governance systems, such as good business ethical practices, as well as other SD-oriented measures, processes and practices should be observed to make EIOs contribute to poverty reduction, shared prosperity and environmentally-sound and socio-economically equitable SD in resources-rich developing countries like Nigeria.

Law as an apparatus of social engineering and positive change in society, which serves the strategic role of governing EIOs, is able to proscribe EIOs regulatory measures to make these operations contribute to poverty reduction and environmentally-sound and socio-economically equitable SD.

Law is certainly able to prescribe appropriate regulatory measures to engender actualisation of the aspiration of the global community, led by the UN, of achieving access to affordable, reliable, sustainable and efficient modern energy for all, stipulated in Goal 7 of the UNSDGs. This Goal is captioned 'affordable and clean energy', and being propagated by an international multistakeholder organisation (Sustainable Energy for All [SEforALL]), to promote energy efficiency and increase the use of renewable energy resources. Law is certainly an instrument of social engineering and positive change in society, which serves the strategic and inevitable role of governing energy resources operations, to stimulate realisation of the dream of the entire global community, by expediting effective energy resource operations, towards providing efficient and sustainable delivery of modern energy services to all societies and individuals, including poor people residing in rural areas of developing countries, by the target year (2030).

However, although law is significant and inevitable in terms of governing behavioural patterns in society, it still remains an unresolved necessity in developing countries, which are suffering from the disease called energy poverty. This is so because energy poverty-afflicted developing countries like Nigeria are yet unable to fully and gainfully utilise law or are reluctant to do so, to address their problems and challenges associated with effective and sustainable energy resource operations, towards efficient delivery of energy services for overall public good. In other words, law is not still being utilised in developing countries which are suffering from energy poverty to boost efficient delivery of energy services for generic public good. It is in this kind of situation that law may be looked at as a victim of bad governance in developing countries. Moreover, law and public good, especially anything associated with overall public good, such as all-embracing wellbeing of people, are victims of bad political leadership and, in effect, bad governance in developing countries, exemplified by developing countries like Nigeria suffering from the disease called energy poverty.

It is therefore the finding of this study that energy poverty in developing countries like Nigeria exists due to bad governance. The study arrives at the finding that Nigeria is afflicted by energy poverty, especially petroleum energy poverty, due to prevailing bad governance in the country. By and large, bad governance has multifaceted, multi-dimensional, versatile and all-encompassing negative effects on the citizenry, humanity and entire fabric of developing countries plagued by it. The study also arrives at the finding that law remains a 
significant, inevitable but ironically an unresolved necessity, especially in developing countries suffering from energy poverty, required to effectively govern energy resources operations towards overall public good.

It is also the finding of this study that law rooted in morality is a significant, inevitable and compelling instrument of GG and SD in society. Accordingly, it is the finding of this study that natural law is the bedrock of virtue, GG and SD. To this end, the essence of good laws entrenched in morality, underscores the effectual and dynamic relationship between law and morality. This study thus promotes and justifies the existence, essence and prevalence of natural law (and its school of thought), as opposed to the positive law theory (and its school of thought).

Consequently, the study recommends that law as an instrument of social engineering and positive change in society, should be fully and gainfully explored and accordingly utilised in developing countries, especially countries suffering from energy poverty. This should be done to efficiently regulate energy resources operations, so as to stimulate realisation of the dream of the entire global community to provide access to energy services for all individuals, including poor people, who are resident in rural areas of developing countries, by 2030.

As a short-term measure, we recommend a pragmatic cost effective approach to and relationship between the efficacy of available non-renewable and renewable energy resources. This measure is to maximise the benefits and minimise the costs associated with utilising ongoing predominant fossil fuels energy resources, as a means towards a rosy long-term potential effective, efficient and sustainable access to renewable energy resources, towards the day-to-day sustenance and survival of humans and society as a whole.

Finally, we recommend that developing countries should readily, fully and gainfully utilise any energy related law or legal instrument associated with or ingrained in morality, that means, having morally good or correct footprint(s), as a veritable mechanism to aid effective and sustainable energy resources operations, towards guaranteeing access to affordable, reliable, sustainable and efficient modern energy services to all and for overall public good, and thereby catalyse the achievement of SD in these countries.

\section{References}

Achebe C., The Trouble with Nigeria (Fourth Dimension 1983).

Adangor Z., Federalism and Natural Resource Governance in Nigeria: An Agenda for Constitutional Reform (Sibon Books 2015).

Adelaja S., The Nigeria Economy: The Way Forward: Taking Nigeria from Economic Recession into Global Economic Dominance (Golden Pen 2017).

Adenikinju A., Iwayemi A. and Iladare W. (eds), Energy Resource Management in a Federal System: Challenges, Constraints and Strategies: Proceedings of the 2013 NAEE/IAEE Conference (Nigerian Association of Energy Economics 2014), 27-28, 223 and 417-500, 538-561.

Akinyetun T. S., Developing in Underdevelopment in Nigeria: The Hand of Corruption (CreateSpace Independent Publishing Platform 2016).

Akpan N. S. and Akpabio E. M., 'Oil and Militancy in Nigeria's Niger Delta: A "Development Catalyst" or “Development in Reverse"?' [2008] 10 (2) South South Journal of Culture and Development, 265-285.

Akobo M. T., Isoun T. T. and Asemota S., (Southern Minorities Movement)/The Willink Commission, NIGERIA Report of the Commission Appointed to Enquire into The Fears of Minorities and The Means of Allaying Them (Southern Minorities Movement [SMM] [reprint] 1996), ii and 94.

Akpan N. S. and Akpabio E. M., 'Oil and Conflicts in the Niger Delta Region, Nigeria: Facing the Facts' [2009] 24 (1) Journal of Social Development in Africa, 9-35.

Akpokodje J. and Salau S., 'Oil Pollution and Agricultural Productivity in the Niger Delta of Nigeria' [2015] 6 (4) Journal of Environmental Economics, 68-75.

Alagoa E. J., Nyananyo B. L. and Allison A. A., (eds), History Concourse 2011: The Niger Delta Environment as Resource and Reserve (Onyoma Research Publications 2012) 217-267.

Albertzart M., Moral Principles (Bloomsbury Ethics) (Bloomsbury Academic 2014). 
Alford C. F., Narrative, Nature, and the Natural Law: From Aquinas to International Human Rights (Palgrave Macmillan 2010).

Alexandra A. and Miller S., Ethics in Practice: Moral Theory and the Professions (The University of New South Wales [UNSW] Press 2009).

Allen F., Implementation of Oil Related Environmental Policies in Nigeria: Government Inertia and Conflict in the Niger Delta (Cambridge Scholars Publishing 2012).

Awoyemi O., The Impact of Oil Pollution on the Environment of the Oil Producing Communities of Nigeria: A Critical Analysis of the Statutory and Regulatory Provisions in Nigeria (Independent Law Publishing 2014).

Ayre G. and Callway R. (eds), Governance for Sustainable Development: A Foundation for the Future (Earthscan 2005).

Azaike S., Inequities in Nigerian Politics (Treasure Communications Resource 2003).

Bannon I. and Collier P.(eds), Natural Resources and Violent Conflict: Options and Actions (The World Bank 2003).

Barrera-Hernandez L., Barton B., Godden L., Lucas A., and Ronne A. (eds), Sharing the Costs and Benefits of Energy and Resources Activity: Legal Change and Impact on Communities (Oxford University Press 2016), especially preview, $\mathrm{v}$ and 1.

Blewitt J., Understanding Sustainable Development (Earthscan 2008).

Bobo's Little Brainiac Books, What Are Fossil Fuels? How Oil Is Made! - Science for Kids (Sunshine in My Soul Publishing 2016).

Bradley R. L. (Jnr) and Fulmer R. W., Energy The Master Resource (Kendall/Hunt Publishing Co. 2004), 4.

Breshears J. D., Natural Law: The Moral Foundation for Social and Political Civility (CentrePointe Publishing 2016).

Bristol-Alagbariya E. T., 'The Concept, Principle, Law and Developmental Practice of Environmental Democracy towards Sustainable Development in Resources-rich Communities of Developing Countries: Focus on Nigeria's Oil Producing Delta Region' [2020] 94 Journal of Law, Policy and Globalization, 53, 55, 61-62, 66 and 69.

Bristol-Alagbariya E. T., 'Duties in Permanent Sovereignty over Natural Wealth and Resources and Petroleum Development in Nigeria: Towards Efficient Government Institutions and Greater Social Responsibility in the Country' [2019] 92 Journal of Law, Policy and Globalization, 78-79, 82 and 89-91.

Bristol-Alagbariya E. T., 'Environmental Assessment Law and Practice in Nigeria towards Achieving the UN Sustainable Development Goals (UNSDGs) in the Country: Cases of SDGs 13 and 17' [2019] 92 Journal of Law, Policy and Globalization, 67, 70-71 and 73.

Bristol-Alagbariya E. T., Governance Towards Sustainable Development in Nigeria: The Role of Strategic Assessment of Decisions \& Actions (Centre for Energy, Petroleum \& Mineral Law \& Policy [CEPMLP]/Dundee University Press [DUP] 2013), xxxvii-xxxvix, xliii - xlvii, 16-17, 35 - 49, 55, 46 - 49, 59- 60, 62 -65, 71 - 72, 111-112, 155, 249-250, 258, 265, $267-268,272-293,288-289$, and 292, 331.

Bristol-Alagbariya E. T., 'Natural Law as Bedrock of Good Governance: Reflections on Alagbariya, Asimini and Halliday-Awusa as Selfless Monarchs towards Good Traditional Governance and Sustainable Community Development in Oil-rich Bonny Kingdom’ [2020] 10 (3) Developing Country Studies, 63-92.

Bristol-Alagbariya E. T., 'Ongoing Reform of the Nigerian Petroleum Industry: The Case of the Oil Producing Communities and Positive Transformation of Nigeria' [2016] 13 (1-2) Environmental and Planning Law Review, 1215-1245. 
Bristol-Alagbariya E. T., Participation in Petroleum Development: Towards Sustainable Community Development in the Niger Delta (CEPMLP]/DUP 2010), 7, 12-16, 28-34, 24, 40 - 43, 45, 49, 73, 75-82, 83101, especially 100, $137-147,196-227,318,323$, and 326-337.

Bristol-Alagbariya E. T., Petroleum Development \& the Environment in Rivers State Nigeria: Fallouts of the UNEP Report on Ogoniland, Environmental Regulatory Standards \& Sustainable Development Laws \& Practices (LAP LAMBERT Academic Publishing 2018), 42, 43, 47, 60.

Bristol-Alagbariya E. T., Primordial Niger Delta, Petroleum Development in Nigeria and the Niger Delta Development Commission Act: A Food For Thought! [2020] 10 (3) Developing Country Studies, 118-119.

Bristol-Alagbariya E. T., 'Nigeria: The Role of Law in Nation-building' (2016) 1 (1) UNIPORT Journal of Public Law, 117-119.

Bristol-Alagbariya E. T., 'Sustainable Development: A Soft Law Concept Transforming SD-Oriented Initiatives of the UN System into Hard Law Instruments in UN Member-states and Promoting Partnerships around the Globe' [2020] 94 Journal of Law, Policy and Globalization, 40, 49 and 50.

Bristol-Alagbariya E. T., 'Theories and the Legal Principle of Permanent Sovereignty over Natural Wealth and Resources in Relation to Petroleum Development in Nigeria' [2019] 4 (2) University of Port Harcourt Journal of Private Law, 208-209.

Bristol-Alagbariya E. T., 'The UN Global Compact as a Soft Law Business Regulatory Mechanism Advancing Corporate Responsibility towards Business Sustainability and Sustainable Development Worldwide' [2020] 94 Journal of Law, Policy and Globalization, 27-39.

Budziszewski J., Written on the Heart: The Case for Natural Law (InterVarsity Press 1997).

Cameron P. D. and Michael M. C., Oil, Gas, and Mining: A Sourcebook for Understanding the Extractive Industries (World Bank Group 2017).

Casper J. K., Greenhouse Gases: Worldwide Impacts (Facts on File 2010).

Clark H., The Importance of Governance for Sustainable Development (The Institute of Southeast Asian Studies [ISEAS] Publishing 2012).

Clark E. V., 'The Politics of Oil in Nigeria: Transparency and Accountability for Sustainable Development in the Niger Delta' [2016] 6 (4) American International Journal of Contemporary Research, 76-82.

Cui R., Oil Multinationals in Nigeria Human Rights, Sustainable Development and the Law (Anchor Academic Publishing 2015).

Daggett C. N., The Birth of Energy: Fossil Fuels, Thermodynamics, and the Politics of Work (Duke University Press Books 2019).

Dalal R. C. and Allen D. E., 'Greenhouse Gas Fluxes from Natural Ecosystems', [2008] 56 (5) Australian Journal of Botany, 369-407.

Dears D. D., Energy: The Source of Prosperity by Donn Dears (Donn D. Dears LLC 2019), particularly 1 - 10.

Decleris M., The Law of Sustainable Development: General Principles: A Report Produced for the European Commission (European Commission 2001).

DeGunther R., Alternative Energy for Dummies (Wiley Publishing Inc. 2009).

Douglas O. and Okonta I., Where Vultures Feast: Shell, Human Rights, and Oil in the Niger Delta (Sierra Club 2001).

Ebegbulem J. C., Ekpe D. and Adejumo T. O., 'Oil Exploration and Poverty in the Niger Delta Region of Nigeria: A Critical Analysis’ [2013] 4 (3) International Journal of Business and Social Science, 279-287. 
Ebeku K. S. A., Oil and the Niger Delta People in International Law: Resource Rights, Environmental and Equity Issues (Rüdiger Köppe Verlag Köln 2006).

Edoh T. and Wuam T. (eds), Democracy, Leadership And Accountability in Post-Colonial Africa: Challenges And Possibilities: Essays in Honour of Professor Akase Paul Sorkaa (Aboki Publishers 2009).

Eleftheriadis P., 'Law and Sovereignty' [2010] 29 (5), Law and Philosophy, 535-569.

Elliott D., Renewables: A Review of Sustainable Energy Supply Options (IOP Publishing 2013).

Epstein A., The Moral Case for Fossil Fuels (Portfolio Penguin Group 2014).

Eseduwo F. S., Gas Flaring and Reinjection Policy-Making in Nigeria: Why Gas Reinjection Policies work in other Oil-producing Countries and Fail in Nigeria (LAP LAMBERT Academic Publishing 2014).

Finnis J., Natural Law \& Natural Rights (Oxford University Press 2011).

Frynas J. G., Oil in Nigeria: Community Rights and Corporate Dominance in Conflict (Lit Verlag 2000).

Frynas J. G., Oil in Nigeria: Conflict and Litigation between Oil Companies and Village Communities (Lit Verlag 2000).

Frynas J. G. and Pegg S. (eds) Transnational Corporations and Human Rights (Palgrave Macmillan 2003).

Fubara D. M. J. (ed), 'The Endangered Environment of the Niger Delta: An NGO Memorandum of the Rivers Chiefs and Peoples' Conference', Port Harcourt, Nigeria, for the World Conference of Indigenous Peoples on Environment and Development and The United Nations Conference on Environment and Development, Rio de Janeiro, Brazil [1992], especially 1 and 16

Garner B. A. (ed), Black’s Law Dictionary (West Group 1999), 889-890, 1049-1050, 1182.

Garner R., Beyond Morality (Echo Point Books \& Media 2014).

Gary I. and Karl T. L., Bottom of the Barrel: Africa's Oil Boom and the Poor (Catholic Relief Services 2003).

Gbemre v The Shell Petroleum Development Company Nigeria Ltd. \& 2 Ors [2005] FHC/B/CS/53/05).

Gillies A., Crude Intentions: How Oil Corruption Contaminates the World (Oxford University Press 2020).

Gilmour B. and Mellett B., 'The Role of Impact and Benefits Agreements in the Resolution of Project issues with First Nations' [2013] 51 (2) Alberta Law Review, 385-400.

Girard R. F. L., Hugo Grotius: Natural Law and Social Contract Theory (CreateSpace Independent Publishing Platform 2014).

Giwa S., Emission Inventory for Gas Flaring in Nigeria: Baseline Black Carbon Emission Inventory for Gas Flaring in the Niger Delta Region of Nigeria (LAP LAMBERT Academic Publishing 2014).

Gomez-Lobo A., Morality and the Human Goods: An Introduction to Natural Law Ethics (Georgetown University Press 2001).

Halley J. M., 'Comparing Aquatic and Terrestrial Variability: At What Scale Do Ecologists Communicate?' [2005] 304, Marine Ecology Progress Series, 274-280.

Hatami M. J., Oilfield Survival Guide, Volume One: For All Oilfield Situations (Oilfield Books 2016).

Helm D., Burn Out: The Endgame for Fossil Fuels (Yale University Press 2017).

Helms L. (ed), Poor Leadership and Bad Governance: Reassessing Presidents and Prime Ministers in North America, Europe and Japan (New Horizons in Leadership Studies Studies) (Edward Elgar Publishing 2012). 
Herman B., Morality as Rationality: A Study of Kant's Ethics (Routledge Library Editions: Kant) (Routledge 2017).

Ikein A. A., The Impact of Oil on a Developing Country: The Case of Nigeria (Praeger Publishers 1990).

International Institute for Environment and Development (IIED) and World Business Council for Sustainable Development (WBCSD), Breaking New Ground: Mining, Minerals and Sustainable Development: The Report of the MMSD Project (Earthscan 2002).

Iwobi E. O., Corruption in the Nigerian Public Service Nipping It in the Bud (Xlibris 2014).

Jaccard M., Sustainable Fossil Fuels: The Unusual Suspect in the Quest for Clean and Enduring Energy (Cambridge University Press 2006).

Jackson R., Sovereignty: The Evolution of an Idea (Key Concepts Series) (Polity 2007).

Jackson T., Prosperity without Growth: Economics for a Finite Planet (Earthscan 2011).

Jackson T., Prosperity without Growth?: The Transition to a Sustainable Economy (Sustainable Development Commission 2009).

Joyce R. and Kirchin S. (eds), A World Without Values: Essays on John Mackie's Moral Error Theory (Philosophical Studies Series) (Springer Science Business Media 2010).

Kemp J., Reason, Action and Morality: International Library of Philosophy and Scientific Method (Humanities Press 1964).

Kemp J., Reason, Action and Morality: Routledge Library Editions; Ethics (Routledge 2020).

Kennett S. A., A Guide to Impact and Benefits Agreements (University of Calgary 1999).

Kiobel v Royal Dutch Petroleum Company [2013] US 133 S Ct. 1659.

Kramer M. H., Where Law and Morality Meet (Oxford University Press 2004).

Kuperberg M., Energy Future: Fossils and Beyond (Dekel Publishing House/Samuel Wachtman's Sons Inc. 2017).

LaFollette H. (ed), Ethics in Practice: An Anthology (Blackwell Philosophy Anthologies) (Blackwell Publishing 2007/John Wiley \& Sons 2014).

Losman D. L., 'The Rentier State and National Oil Companies: An Economic And Political Perspective' [2010] 64 (3) Middle East Journal, 427-445.

Mahmud S. S., State, Class and Underdevelopment in Nigeria and Early Meiji Japan (Palgrave Macmillan 1996).

Maiangwa B. and Agbiboa D. E., 'Oil Multinational Corporations, Environmental Irresponsibility and Turbulent Peace in the Niger Delta' [2013] 48 (2) Africa Spectrum, 71-83.

Manby B., The Price of Oil: Corporate Responsibility and Human Rights Violations in Nigeria's Oil Producing Communities (Human Rights Watch 1999), 146-169.

Manirabona A. and Cárdenas Y. V., Extractive Industries and Human Rights in an Era of Global Justice: New Ways of Resolving and Preventing Conflicts (LexisNexis Canada 2019).

Minkkinen P., Sovereignty, Knowledge: A Glasshouse Book (Routledge 2009).

Mirovitskaya N. and Asher W. (eds), Guide to Sustainable Development and Environmental Policy (Duke University Press 2001) 9 and 17.

Murphy J. B., The Philosophy of Positive Law: Foundations of Jurisprudence (Yale University Press 2005). 
Norman R., The Moral Philosophers: An Introduction to Ethics (Oxford University Press 1998).

Nweke K. and Nkwede J. O., 'The Nigerian State and Hobbes' Social Contract Theory: An Albatross around the Collective Will of the People' [2019] 152 (3) European Journal of Scientific Research, 304-321.

Nwoba O. E. M. and Abah E. O., 'Impact of Crude Oil Revenue (COR) On Economic Growth in Nigeria (19602010)’ [2017] 22 (7) IOSR Journal of Humanities and Social Science (IOSR-JHSS), 85-99.

Nye J. S., Zelikow P. D. and King D. C., Why People Don't Trust Government (Harvard University Press 1997).

Obi C. I., 'Oil Extraction, Dispossession, Resistance, and Conflict in Nigeria's Oil-Rich Niger Delta' [2010] 30 (1-2) Canadian Journal of Development Studies, 219-236.

Obi C., 'Oil as the 'Curse' of Conflict in Africa: Peering through the Smoke and Mirrors' [2010] 37 (126) Review of African Political Economy, 483-495.

Obi C. and Rustad S. A. (eds), Oil and Insurgency in the Niger Delta: Managing the Complex Politics of Petroviolence (Zed Books 2011).

Odigie E., Associated Gas Injection Feasibility in the Niger Delta: A Case Study of the Southern Swamp Fields (Nigeria) (LAP LAMBERT Academic Publishing 2013).

O'Faircheallaigh C., 'Community Development Agreements in the Mining Industry: An Emerging Global Phenomenon' [2013] 44 (2) Community Development, 222-238.

Ogbuigwe A., Legal Issues in the Niger Delta Resource Dilemma: A Collection of Essay (Anpez Centre for Environment and Development 2018), 15 and 17.

Ogbuigwe A., Offended: Legal Issues in the Niger Delta Struggle (Anpez Centre for Environment and Development 1999), especially 2-43 and 187-193.

Ogidiolu A., 'Effects of Gas Flaring on Soil and Vegetation Characteristics in Oil Producing Region of Niger Delta, Nigeria' [2003] 1 (1), International Journal of Ecology and Environmental Dynamics, 47-53.

Ojakorotu V. (ed), Fresh Dimensions on the Niger Delta Crisis of Nigeria (JAPSS Press 2009).

Ojakorotu V., Oil Exploitation and Conflict in the Niger-Delta Region of Nigeria (APSS Press 2009).

Ojeme J. O., 'A Critical Appraisal of African Largest Economy Ravaged in Poverty \& Destitution (A Case Study of Nigeria in the Light of the Recent Rebasing Nigerian GDP)'[2017] 3 (2) International Institute of Academic Research and Development (IIARD), 29-52.

Olawuyi D. S., Extractives Industry Law in Africa (Springer Nature Switzerland AG 2018).

Okene O. V. C. (ed), Readings in Law and Policy (Current Issues and Trends): (In Commemoration of the Golden Jubilee of Rivers State (1967-2017) (Faculty of Law, Rivers State University 2017) 129-144.

Okonjo-Iweala N., Fighting Corruption Is Dangerous: The Story Behind the Headlines (The Massachusetts Institute of Technology [MIT] Press 2018).

Oluduro O., 'Oil Exploitation and Human Rights Violations in Nigeria's Oil Producing Communities' [2012] 25 (2) Afrika Focus, 160-166.

Omeje K. (ed), Extractive Economies and Conflicts in the Global South: Multi-Regional Perspectives on Rentier Politics (Ashgate Publishing 2008).

Omeje K., High Stakes and Stakeholders: Oil Conflict and Security in Nigeria (Routledge 2016).

Omeje K., 'The Rentier State: Oil-related Legislation and Conflict in the Niger Delta, Nigeria [2007] 6 (2) Conflict, Security \& Development, 211-230. 
Omofonmwan S. I. and Odia L. O., 'Oil Exploitation and Conflict in the Niger-Delta Region of Nigeria' [2009] 26 (1) Journal of Human Ecology, 25-30.

Omorogbe Y. and Ordor A. O. (eds), Ending Africa's Energy Deficit and the Law: Achieving Sustainable Energy for All (Oxford University Press, 2018), 5, 12-13, 20 - 21, 131, 162, 209, 377, 380-381 and 384.

Omotola J. S., 'From the OMPADEC to the NDDC: An Assessment of State Responses to Environmental Insecurity in the Niger Delta, Nigeria' [2007] Africa Today, 73-89.

Omoweh D. A., Shell Petroleum Development Company, The State and Underdevelopment of Nigeria's Niger Delta: A Study in Environmental Degradation (Africa World Press 2006).

Onimode B., Imperialism and Underdevelopment in Nigeria: The Dialectics of Mass Poverty (Zed Press 1982).

Onuoha A., From Conflict to Collaboration: Building Peace in Nigeria's Oil-Producing Communities (Adonis \& Abbey Publishers 2005).

Osha S., Ken Saro-Wiwa's Shadow: Politics, Nationalism and the Ogoni Protest Movement (Adonis \& Abbey Publishers 2007).

Osita-Njoku A., 'The Political Economy of Development in Nigeria: From the Colonial to Post Colonial Eras' [2016] 21 (9), IOSR Journal of Humanities and Social Science (IOSR-JHSS), 9-15, especially 9 and 13-14.

Oyende K., Oil Pollution Law and Governance in Nigeria (Stirling-Horden Publishers 2017).

Parker L., Climate Change: Design Approaches for a Greenhouse Gas Reduction Program (BiblioGov 2013).

Pearce D. W. and Turner R. K., Economics of Natural Resources and the Environment (The John Hopkins University Press 1990).

Peel M., A Swamp Full of Dollars: Pipelines and Paramilitaries at Nigeria's Oil Frontier (Lawrence Hill Books/Chicago Review Press 2009/I. B. Tauris \& Co 2011).

Quinn W., Morality and Action: Cambridge Studies in Philosophy (Cambridge University Press 2003).

Rasband J., Salzman J., Squillace M. and Kalen S., Natural Resources Law and Policy (Foundation Press 2016).

Rexler J., 'Beyond the Oil Curse: Shell, State Power, and Environmental Regulation in the Niger Delta' [2010] 12 (1) Stanford Journal of International Relations, 26-31.

Rice C. E., 50 Questions on the Natural Law: What It Is and Why We Need It (Ignatius Press 1999).

Roosevelt C., The Science of Government, Founded On Natural Law (Nabu Press 2014).

Roston E., The Carbon Age: How Life's Core Element Has Become Civilization's Greatest Threat (Walker \& Company 2009).

Rousseau J., The Social Contract (Wordsworth Classics of World Literature) (Wordsworth Editions 1998).

Rousseau J., The Social Contract or Principles of Political Right (Aziloth Books 2011).

Sachs B., Explaining Right and Wrong: A New Moral Pluralism and Its Implications (Routledge Studies in Ethics and Moral Theory (Routledge 2017).

Sachs J. F., The Age of Sustainable Development (University of Columbia Press 2015).

Sacks J., Morality: Restoring the Common Good in Divided Times (Hodder \& Stoughton 2020).

Salem Press, Ethics: Questions \& Morality of Human Actions (H.W. Wilson Publishing Co. 2019).

Sapat A. (ed), Routledge Handbook of Environmental Governance (Routledge 2017). 
Sayne A., Gillies A. and Katsouris C., Inside NNPC Oil Sales: A Case for Reform in Nigeria (Natural Resource Governance Institute 2015).

Schobert H. H., Energy and Society: An Introduction (CRC Press 2014), 1-10, 270 - 273.

Segger M. C. and Khalifan A., Sustainable Development Law: Principles, Practices, and Prospects (Oxford University Press 2004).

Sidaway R., Resolving Environmental Disputes from Conflicts to Consensus (Earthscan 2013).

Sigmund P. E., Natural Law in Political Thought (University Press of America 1981).

Smith D. J., A Culture of Corruption: Everyday Deception and Popular Discontent in Nigeria (Princeton University Press (2008).

Spielthenner G., 'What Makes Actions Morally Good?' [2005] VII (1) Etica \& Politica/Ethics \& Politics, 1-13.

Stevens P. J., 'The Resource Curse and How to Avoid It' [2006] 31 (1) The Journal of Energy and Development, $1-20$.

Stevens P. J., 'The Resource Curse Revisited Appendix: A Literature Review' [2015] The Royal Institute of International Affairs, 1-42.

Sutton J. R., Law/Society: Origins, Interactions, and Change (Pine Forge Press 2001).

Tamuno T., Oil Wars in the Niger Delta 1849 -2009 (Stirling-Horden Publishers 2011).

Ugoh S. C. and Ukpere W. I., Environmental Policy in Nigeria: Paradox of Niger Delta Sustainable Development [2012] 37 (3) Journal of Human Ecology, 151-158.

United Nations Environment Programme [UNEP], Environmental Assessment of Ogoniland (UNEP 2011).

UNEP, Healthy Environment, Healthy People (UNEP 2016).

Usher B., Renewable Energy: A Primer for the Twenty-First Century (Columbia University Press 2019).

Usman A. K., Nigerian Oil and Gas Industry Laws (Malthouse Press 2017).

van der Ploeg F., 'Natural Resources: Curse Or Blessing?' [2011] 49 (2) Journal of Economic Literature, 366420.

Wangbu J. K., The Niger Delta Paradox Impoverished in the Midst of Abundance (Safari Books 2018).

Ward P. L., What Really Causes Global Warming?: Greenhouse Gases or Ozone Depletion? (Morgan James Publishing 2015).

Watts M. (eds), Curse of the Black Gold: 50 Years of Oil in The Niger Delta (powerHouse [pH]Books 2010).

Watts M., 'Petro-Insurgency or Criminal Syndicate? Conflict \& Violence in the Niger Delta' [2007] 43 (114) Review of African Political Economy, 637-660.

Weinreb L. L., Natural Law and Justice (Harvard University Press 1990).

Westberg D., 'The Relation between Positive and Natural Law in Aquinas' [1994-1995] 11 (1), Journal of Law and Religion, 1-22.

Wiwa et al. v Brian Anderson et al., Case No. 01 Civ. 1909 (KMV) (HBP) (SDNY).

Wiwa et al. v Royal Dutch Petroleum Company, et al., Case No. 96 Civ. 8386 (KMW) (HBP) (Southern District of New York [SDNY]).

Wiwa $v$ Shell Petroleum Development Company of Nigeria Limited (SPDC), 04 Civ. 2665, (SDNY). 
World Commission on Environment and Development (WCED), Our Common Future (Oxford University Press 1987), $\mathrm{x}-23,168-169,171$ and 181-189, 192-202.

World Energy Council (WECouncil), World Energy Resources 2016 (WECouncil 2016).

Wuam T. and Sunday T. N. (eds), Governance and Economic Development in the Fourth Republic (Aboki Publishers 2010).

Yusuf M., The Relationship between Good Governance and Poverty in Nigeria (LAP LAMBERT Academic Publishing 2015). 